\title{
Influence of Light Conditions on Microalgae Growth and Content of Lipids, Carotenoids, and Fatty Acid Composition
}

\author{
Yevhen Maltsev ${ }^{1, *(1)}$, Kateryna Maltseva ${ }^{2}$, Maxim Kulikovskiy ${ }^{1}$ and Svetlana Maltseva ${ }^{1}$ \\ 1 Laboratory of Molecular Systematics of Aquatic Plants, K.A. Timiryazev Institute of Plant Physiology RAS, \\ IPP RAS, 127276 Moscow, Russia; max-kulikovsky@yandex.ru (M.K.); svetadm32@gmail.com (S.M.) \\ 2 Faculty of Chemistry and Biology, Bogdan Khmelnitsky Melitopol State Pedagogical University, \\ 72312 Melitopol, Ukraine; katti_m@ukr.net \\ * Correspondence: ye.maltsev@gmail.com
}

Citation: Maltsev, Y.; Maltseva, K.; Kulikovskiy, M.; Maltseva, S. Influence of Light Conditions on Microalgae Growth and Content of Lipids, Carotenoids, and Fatty Acid Composition. Biology 2021, 10, 1060. https://doi.org/10.3390/ biology10101060

Received: 14 September 2021

Accepted: 14 October 2021

Published: 18 October 2021

Publisher's Note: MDPI stays neutral with regard to jurisdictional claims in published maps and institutional affiliations.

Copyright: (C) 2021 by the authors Licensee MDPI, Basel, Switzerland. This article is an open access article distributed under the terms and conditions of the Creative Commons Attribution (CC BY) license (https:/ / creativecommons.org/licenses/by/ $4.0 /)$.
Simple Summary: Microalgae are a valuable natural resource for a variety of value-added products. This determines the relevance of developments aimed at increasing the efficiency of their cultivation. First of all, the growth of microalgae is determined by the impact of light. The main parameters characterizing the light conditions during the cultivation of microalgae are light intensity, duration of lighting, and the use of rays of different spectral composition. Manipulations with the duration of the photoperiod and the use of pulsed light can avoid photodamage of microalgae cells and create conditions for the most efficient absorption of light photons. The optimal light conditions for photosynthesis, growth, accumulation of lipids, fatty acid composition, and carotenes content differ both in different taxonomic groups of microalgae and in different strains of the same species.

Abstract: Microalgae are a valuable natural resource for a variety of value-added products. The growth of microalgae is determined by the impact of many factors, but, from the point of view of the implementation of autotrophic growth, light is of primary importance. This work presents an overview of the influence of light conditions on the growth of microalgae, the content of lipids, carotenoids, and the composition of fatty acids in their biomass, taking into account parameters such as the intensity, duration of lighting, and use of rays of different spectral composition. The optimal light intensity for the growth of microalgae lies in the following range: $26-400 \mu \mathrm{mol}$ photons $\mathrm{m}^{-2} \mathrm{~s}^{-1}$. An increase in light intensity leads to an activation of lipid synthesis. For maximum lipid productivity, various microalgae species and strains need lighting of different intensities: from 60 to $700 \mu \mathrm{mol}$ photons $\mathrm{m}^{-2} \mathrm{~s}^{-1}$. Strong light preferentially increases the triacylglyceride content. The intensity of lighting has a regulating effect on the synthesis of fatty acids, carotenoids, including $\beta$-carotene, lutein and astaxanthin. In intense lighting conditions, saturated fatty acids usually accumulate, as well as monounsaturated ones, and the number of polyunsaturated fatty acids decreases. Red as well as blue LED lighting improves the biomass productivity of microalgae of various taxonomic groups. Changing the duration of the photoperiod, the use of pulsed light can stimulate microalgae growth, the production of lipids, and carotenoids. The simultaneous use of light and other stresses contributes to a stronger effect on the productivity of algae.

Keywords: carotenoids; fatty acids; light; lipids; microalgae; photoperiod

\section{Introduction}

Microalgae (eukaryotic and prokaryotic cyanobacteria) are a large group of photoautotrophic organisms, as well as organisms capable of heterotrophic, mixotrophic, and photoheterotrophic existence [1,2]. They are adapted to life in a variety of habitats and produce biomass containing a wide variety of compounds that can be used in the food, pharmaceutical, and cosmetic industries, and for the production of biofuels, etc. [3-6]. Of significant interest to the food and feed industry is the ability of microalgae to produce 
carotenoids such as $\beta$-carotene, astaxanthin, lutein, as well as lipids containing a wide variety of fatty acids, including long-chain polyunsaturated fatty acids (PUFAs) from the omega-3 and omega-6 [7-13] group.

To meet the needs of the market for these products, an extremely important task is to find and introduce highly productive microalgae species into the culture, to determine the optimal cultivation conditions and technologies that meet the requirements of commercial feasibility. Recent reviews reveal major advances in research on the ability of microalgae to produce carotenoids, lipids, valuable fatty acids, and the possibilities and prospects of metabolic engineering to increase their production $[13,14]$.

It has also been reported about the great possibilities of regulating the yield of commercially valuable bioproducts when using the main abiotic stress factors during the cultivation of microalgae [15-18]. The main achievements in this regard have been generalized in a number of recent reviews [11,19-21]. These reviews discuss the main results of the influence of all the main abiotic factors: changes in lighting and cultivation temperature, limitation of nitrogen and phosphorus in nutrient media, the use of salt stress, ultraviolet and magnetic radiation, the influence of heavy metals on the growth rate of microalgae, the productivity of lipids, carotenoids, fatty acids. The concentration in one work of all the variety of stress factors is very valuable in terms of a systemic approach to this problem, but inevitably leads to certain limitations associated with the inability to enter into details.

The growth of microalgae is determined by the action of many factors, but, from the point of view of the implementation of autotrophic growth, light is of primary importance. It determines the functional state, growth, and reproduction of photoautotrophic microalgae and plants, and also has a direct effect on the metabolism of both mixotrophic microalgae, capable of combining autotrophic and heterotrophic types of nutrition, and photoheterotrophic ones [22-24].

In natural habitats, the light conditions for the growth of microalgae are determined by the geographical latitude of the area, daily and seasonal changes in the solstice altitude, light scattering by the atmosphere, water column, etc. and are very variable. Accordingly, microalgae are adapted to various lighting conditions. There are species that are found in highly shaded habitats, for example, in the soil under the dense canopy of higher plants [25,26], above-water and underwater caves, in deep water layers [27-29]. Other species are adapted to growth in direct sunlight, for example, in polar, tropical deserts [30-32], on salt marshes and other open surfaces [33-36], where the light intensity can reach $2000 \mu \mathrm{mol}$ photons $\mathrm{m}^{-2} \mathrm{~s}^{-1}$ [15].

When cultivating microalgae, both natural and artificial lighting are used. Natural light is used for growing microalgae in open systems and cannot be purposefully controlled. In closed growing systems-photobioreactors-artificial lighting is applicable. In this case, the lighting conditions can be changed and this can be used to increase the productivity of microalgae biomass and the accumulation of valuable compounds in it. An urgent task in the microalgae cultivation is to minimize the energy costs for providing lighting, since they largely determine the cost of compounds obtained from microalgae [37]. The main parameters characterizing the lighting conditions are light intensity, duration of lighting, and the use of rays of different spectral composition. These parameters can be changed individually and in various combinations when cultivating microalgae.

The purpose of this article is to summarize information on the effect of lighting conditions on the growth of microalgae, the content of lipids, carotenoids, and the composition of fatty acids in their biomass, taking into account such parameters as the intensity, duration of lighting and the use of rays of different spectral composition. We assume that the information provided will be valuable for further developments to increase the efficiency of cultivation of microalgae species and obtain value-added products from their biomass, such as carotenoids, lipids, and fatty acids by changing certain lighting parameters. 


\section{Light as an Environmental Factor of Microalgae Growth}

It is known that low lighting can have a limiting effect on the microalgae growth, and too high lighting can have an inhibitory one [38-40]. The light intensity directly affects the photosynthesis rate, and this dependence is known to be expressed by a logarithmic curve [41]. At low light intensity, an increase in lighting leads to an almost linear increase in the photosynthesis rate. However, in the region of saturating light intensities, a further increase in lighting does not increase the photosynthesis rate. Microalgae vegetation under excessive light can lead to photo-oxidative damage to the photosynthetic apparatus, and decrease in the efficiency and rate of photosynthesis, i.e. to photoinhibition [15].

The molecular mechanisms of photoinhibition are quite complex. Enhanced production of reactive oxygen species (ROS) can occur during photoinhibition in cells. ROS are highly reactive [21,42]. In small amounts, they perform a signaling function and trigger various mechanisms to counteract stress, but their high concentrations lead to damage of cell structures, transformation of physiological and biochemical processes. In response to oxidative stress, synthesis of antioxidant enzymes, phytohormones, and other photoprotective compounds can be observed in algal cells, due to the oxidation of which, reactions that are more dangerous for the cell can be interrupted [15,42]. Also, as a response to stress there are changes in photosystems, the composition and ratio of the components of the light-harvesting complex, the accumulation of lipids, carotenoids, and the composition of fatty acids [14,43-45]. Thus, oxidative stress can significantly improve the commercial characteristics of algal species. In this case, the main task is to achieve an optimal balance between the growth rate of microalgae and induction of compounds valuable from a biochemical point of view.

When discussing the regulatory effect of light on the growth of microalgae, as a rule, not the entire light flux is studied, but that part of it that has the greatest physiological activity. This radiation corresponds to the visible part of the spectrum in the wavelength range $400-700 \mathrm{~nm}$ and is called photosynthetically active radiation [46]. When characterizing the light conditions for microalgae growth, the light intensity, duration of lighting and the spectral composition of the light flux are taken into account.

Intensity is a quantitative characteristic of light. There is no common approach to measuring light intensity among researchers. The energy quantitative characteristic of light radiation is the flux of radiant energy, which arrives at the surface perpendicular to the rays per unit of time. To determine the intensity of photosynthetically active light flux, an estimate of the number of photons is widely used, expressing them in micro Einsteins $\left(\mu \mathrm{E} \mathrm{m}^{-2} \mathrm{~s}^{-1}\right)$ or in micromoles ( $\left.\mu \mathrm{mol} \mathrm{m}^{-2} \mathrm{~s}^{-1}\right)$ per unit area per second [18,47-49]. The light intensity can also be presented in lux ( $1 \mathrm{~lx}=1$ lumen per square meter) or $\mathrm{W} \mathrm{m}^{-2}[50,51]$. As the analysis of publications [18,47-51] shows, when studying the effect of light on the growth and production characteristics of microalgae, different units of measurement are also used, which creates certain difficulties in comparing the results obtained. Online calculators can be used to convert different units of lighting radiation. An intensity of $250 \mathrm{~lx}$ for the incandescent tungsten halogen lamp equivalents to $5 \mu \mathrm{mol} \mathrm{m}^{-2} \mathrm{~s}^{-1}$ and $1 \mathrm{~W} \mathrm{~m}^{-2}$. But an intensity of $250 \mathrm{~lx}$ for the cool white fluorescent lamp corresponds to $3.5 \mu \mathrm{mol} \mathrm{m}^{-2} \mathrm{~s}^{-1}$ and $0.763 \mathrm{~W} \mathrm{~m}^{-2}$ [52].

The duration of lighting is also of great importance, both from the point of view of ensuring maximum microalgae productivity, and for minimizing energy costs during cultivation. The practice of using continuous lighting or alternating light and dark cultivation cycles is known, including pulsed (blinking) lighting, which is characterized by a rapid change in light and dark periods $[46,53,54]$. The use of light and dark cultivation cycles is associated with the peculiarities of photosynthesis-a complex multistep process in which light-dependent photochemical reactions and dark reactions are distinguished, wherein the dark reaction of photosynthesis is not dependent on the presence of light [14].

When assessing the effect of lighting conditions on the growth and production characteristics of microalgae, many researchers also pay attention to the cell density in the cultures [38]. High cell density prevents light penetration, which in turn leads to a decrease 
in the intensity of photosynthesis [55]. To improve the lighting conditions, it is recommended to regulate the cell density, provide the stirring of the cultures, and change the area of the illuminated surface and the shape of the bioreactors, etc. This issue is discussed in detail in several research works $[43,45,56]$.

Algae pigments provide the absorption of light energy. When a light quantum is absorbed, the pigment molecules are excited and is converted into a high-energy state. When they return to their initial state, they release energy due to which photochemical transformations occur [57]. The process of absorption of light energy, the structure of light-harvesting complexes of microalgae, and the features of energy transfer to the reaction centers of photosystems I and II are described in detail $[14,56,58]$. Each microalgae photosystem contains a distinctive set of light-harvesting pigments that provide a unique absorption spectrum (Table 1).

Table 1. Main pigments of algal photosystems and absorption maxima of light waves.

\begin{tabular}{|c|c|c|c|}
\hline Pigments & $\begin{array}{l}\text { Absorption Maxima in } \\
\text { Organic Solvents }{ }^{*}, \mathrm{~nm}\end{array}$ & Representatives & References \\
\hline chlorophyll $a$ & 420,660 & All algae & {$[57,59]$} \\
\hline chlorophyll $b$ & 435,643 & Green algae & {$[59,60]$} \\
\hline chlorophyll $c$ & 445,625 & $\begin{array}{c}\text { Heterokontophyta, Haptophyta, Dinophyta, } \\
\text { Cryptophyta }\end{array}$ & {$[59,61]$} \\
\hline chlorophyll $d$ & 450,690 & Rhodophyta, some Cyanobacteria & {$[40,59]$} \\
\hline chlorophyll $f$ & 707 & Some Cyanobacteria & {$[40,59,62]$} \\
\hline$\beta$-carotene & $425,450,480$ & Most algae & {$[57,59]$} \\
\hline$\alpha$-carotene & $420,440,470$ & $\begin{array}{l}\text { Some algae (Cryptophyta, Haptophyta, Dinophyta, } \\
\text { Chrysophyceae), some Cyanobacteria }\end{array}$ & {$[58,63]$} \\
\hline fucoxanthin & $425,450,475$ & $\begin{array}{l}\text { Heterokontophyta (Bacillariophyceae Phaeophyceae, } \\
\text { Chrysophyceae), Haptophyta }\end{array}$ & {$[64]$} \\
\hline phycoerythrin & $490,546,576$ & Rhodophyta, Cryptophyta, Cyanobacteria & {$[58,65]$} \\
\hline phycocyanin & 618 & Rhodophyta, Cryptophyta, Cyanobacteria & {$[58,65]$} \\
\hline allophycocyanin & 650 & Rhodophyta, Cryptophyta, Cyanobacteria & {$[65]$} \\
\hline
\end{tabular}

* Pigment absorption maxima may vary with different solvents [64].

In addition to chlorophyll $a$, other types of chlorophyll are known in microalgae: $b, c$, $d$, and $f$ in some cyanobacteria [40,60-62]. All chlorophylls are magnesium complexes of various tetrapyrroles [57]. Chlorophylls selectively absorb light in the red and blue spectral region [59]. Moreover, the absorption spectrum of each of the chlorophylls has its own characteristics [66]. Algal cells contain either only chlorophyll $a$ or chlorophyll $a$ as the main one and other chlorophylls as the second additional pigment $[57,62,66]$.

Phycobilins provide additional light absorption in the 490-650 $\mathrm{nm}$ range [65]. The phycobilins of cyanobacteria are not identical to those of Rhodophyta and are named, respectively, C-phycocyanin, C-phycoerythrin and R-phycocyanin and R-phycoerythrin. Cryptophyta phycobilins are subdivided into phycoerythrins (Cr-PE) or phycocyanins (Cr-PC), but neither Cryptophyta species contains both [58]. The spectral characteristics of phycobilins have slight differences in different species [65].

Another large group of accessory pigments are carotenoids. The absorption spectra of carotenoids are in the range 400-500 nm [67]. Carotenoids are a widespread group of pigments. Currently, as noted by Wan et al. [13], there are over 1100 carotenoids. Depending on the availability of oxygen, carotenoids are divided into carotenes, pigments that do not contain oxygen, and xanthophylls, pigments that contain oxygen [67]. The most common carotenoids in microalgae are $\beta$-carotene and xanthophylls-lutein, violaxanthin, zeaxanthin [20,67].

Carotenoids associated with the photosynthetic apparatus of microalgae and providing the absorption of light energy are referred to as primary carotenoids [21]. It is reported that their diversity is significantly lesser than that of secondary carotenoids, which are not associated with the provision of photosynthesis and vary significantly in different 
taxonomic groups of algae [68]. Secondary carotenoids are often produced by cells in response to specific environmental conditions, such as strong light. They accumulate in the peripheral cytoplasm or plastid stroma [20]. Carotenoid's characteristic of the photosynthetic apparatus of algae, for example, $\beta$-carotene, lutein, can also accumulate as secondary carotenoids [21]. Widely known secondary carotenoids are astaxanthin, the end product of the biosynthesis of secondary carotenoids in a number of microalgae, and canthaxanthin $[68,69]$.

From the ecological and physiological points of view, the different composition of microalgae pigments demonstrates differences in the ability of algae to use light of different spectral composition for photosynthesis and to develop niches with different lighting conditions $[18,27,30,70]$. Therefore, when cultivating microalgae, the spectral composition of light is an important growth parameter [71,72].

To provide lighting, fluorescent lamps or LEDs are used [73]. Spectrally, the light of a luminescent lamp has maxima in the blue-violet part of the spectrum, valuable from the point of view of ensuring photosynthesis. The red part of the spectrum contains an insignificant part of light energy [74]. Unlike fluorescent lamps, the use of LEDs allows you to create lighting with a certain wavelength, create monochromatic lighting or lighting with light fluxes with a specially selected spectral composition [73]. A feature of LEDs is the ability to produce a high-intensity luminous flux, which is similar in spectral composition to the sun. For example, a white LED has two pronounced maxima of approximately the same intensity, falling on the part of the spectrum with a wavelength of $450 \mathrm{~nm}$ and $550-650 \mathrm{~nm}$ [74]. It should also be noted that the use of LED lighting can significantly reduce the energy intensity of production $[71,75,76]$.

\section{Influence of Lighting Intensity}

\subsection{Optimal and Photoinhibiting Light Intensity}

Algae grown under various light intensities show changes in biomass formation rate, pigment and lipid content, fatty acid composition, and ratio. For this purpose, various researchers have studied a fairly wide range of light intensity: from 5 to $3500 \mu \mathrm{mol}$ photons $\mathrm{m}^{-2} \mathrm{~s}^{-1}[31,43,47,53,77-80]$.

The optimal values of the light intensity at which the maximum growth rate is observed for different taxonomic groups and species of algae, as our analysis of publications shows, are in the range of 26-400 $\mu \mathrm{mol}$ photons $\mathrm{m}^{-2} \mathrm{~s}^{-1}$ (Table 2). Only a few species show extremely high adaptability to high light levels and thus highly effective photoprotection mechanisms. An example of this is Dunaliella salina, some strains of which had maximum growth under lighting of $1000 \mu \mathrm{mol}$ photons $\mathrm{m}^{-2} \mathrm{~s}^{-1}$ [48].

Table 2. Optimal light intensity values for the maximum growth rate of algae from different taxonomic groups.

\begin{tabular}{|c|c|c|c|c|c|}
\hline $\begin{array}{c}\text { Investigated Light } \\
\text { Intensity, } \mu \mathrm{mol} \text { photons } \\
\mathrm{m}^{-2} \mathrm{~s}^{-1}\end{array}$ & $\begin{array}{c}\text { Optimal Light } \\
\text { Intensity for } \\
\text { Maximum Growth, } \\
\mu \mathrm{mol} \text { photons } \mathrm{m}^{-2} \mathrm{~s}^{-1}\end{array}$ & $\begin{array}{l}\text { Maximum } \\
\text { Growth Rate } \\
\left(d^{-1}\right)\end{array}$ & Species and Strain & Class & References \\
\hline $5,25,50,100,250,850$ & $26-55$ & 1.3 & $\begin{array}{l}\text { Microchloropsis salina } \\
(=\text { Nannochloropsis salina })\end{array}$ & Eustigmatophyceae & [43] \\
\hline $60,100,250,500,750$ & $60-112$ & * & Phaeodactylum tricornutum & Bacillariophyceae & [81] \\
\hline $70,140,210$ & 70 & * & Porphyridium purpureum & Porphyridiophyceae & [82] \\
\hline $\begin{array}{c}10,20,40,60,80,100,120, \\
140,160,180,200,220,240, \\
260,300\end{array}$ & $60-100$ & $0.6-0.7$ & Rhodomonas salina & Cryptophyceae & [83] \\
\hline $60,195,330,465,600$ & $110-220$ & $>1.0$ & Rhodomonas sp. & Cryptophyceae & [84] \\
\hline $50,125,325$ & 325 & 1.1 & Isochrysis galbana & Coccolithophyceae & [85] \\
\hline $10,50,150,200,350,1000$ & 150 & 0.8 & $\begin{array}{l}\text { Tetradesmus obliquus } \\
\text { (=Scenedesmus obliquus) }\end{array}$ & Trebouxiophyceae & [53] \\
\hline $50,150,300$ & 150 & * & Scenedesmus obliquus & Trebouxiophyceae & [86] \\
\hline $50,150,300$ & 150 & * & Chlorella vulgaris & Trebouxiophyceae & [86] \\
\hline
\end{tabular}

${ }^{*}$ Data not available. ${ }^{a}$ Approximate values obtained from figures. ${ }^{b}$ Doubling time (h). 
Table 2. Cont.

\begin{tabular}{|c|c|c|c|c|c|}
\hline $\begin{array}{c}\text { Investigated Light } \\
\text { Intensity, } \mu \mathrm{mol} \text { photons } \\
\mathrm{m}^{-2} \mathrm{~s}^{-1}\end{array}$ & $\begin{array}{c}\text { Optimal Light } \\
\text { Intensity for } \\
\text { Maximum Growth, } \\
\mu \text { mol photons } \mathrm{m}^{-2} \mathrm{~s}^{-1}\end{array}$ & $\begin{array}{l}\text { Maximum } \\
\text { Growth Rate } \\
\quad\left(\mathbf{d}^{-1}\right)\end{array}$ & Species and Strain & Class & References \\
\hline 150,300 & 150 & 0.77 & $\begin{array}{l}\text { Chromochloris zofingiensis } \\
\text { (=Chlorella zofingiensis) }\end{array}$ & Trebouxiophyceae & [87] \\
\hline $35,200,400$ & 400 & $0.2^{\mathrm{a}}$ & $\begin{array}{l}\text { Lobosphaera incisa } \\
\text { (=Parietochloris incisa) }\end{array}$ & Trebouxiophyceae & [88] \\
\hline 133,182 & 133 & $*$ & Tetraselmis sp. & Chlorodendrophyceae & [89] \\
\hline $200,500,1000,1500$ & 1000 & $\begin{array}{c}0.2 \text { (DF15) } 0.55 \\
\text { (UTEX 2538) } \\
1.3 \text { (CCAP }\end{array}$ & $\begin{array}{l}\text { Dunaliella salina } \\
\text { (DF15, UTEX 2538) }\end{array}$ & Chlorophyceae & [48] \\
\hline $200,500,1000,1500$ & 1500 & $\begin{array}{c}19 / 30) \\
1.05 \text { (DF17) } \\
0.75 \text { (DF40) }\end{array}$ & $\begin{array}{c}\text { Dunaliella salina } \\
\text { (CCAP 19/30, DF17, DF40) }\end{array}$ & Chlorophyceae & [48] \\
\hline $20-500$ & 330 & 1.78 & Arthrospira fusiformis & Cyanophyceae & [90] \\
\hline $200-700$ & 360 & 0.26 & Arthrospira fusiformis & Cyanophyceae & [91] \\
\hline 40,160 & 160 & 0.491 & Phormidium sp. & Cyanophyceae & [92] \\
\hline $75,100,150,500,660,750$ & 660 & $2.14^{\mathrm{b}}$ & $\begin{array}{l}\text { Synechococcus sp. } \\
\text { PCC } 11901\end{array}$ & Cyanophyceae & [93] \\
\hline $75,100,150,500,660,750$ & 500 & $1.93^{b}$ & $\begin{array}{l}\text { Synechococcus sp. } \\
\text { UTEX } 2973\end{array}$ & Cyanophyceae & [93] \\
\hline
\end{tabular}

* Data not available. ${ }^{a}$ Approximate values obtained from figures. ${ }^{b}$ Doubling time (h).

It is known that not all light energy absorbed by the photosynthetic apparatus of algae can be used for photosynthetic reactions. When the maximum rate of photosynthesis is reached, the excess light flux continues to be absorbed by the cell and this leads to a state of light saturation of photosynthesis. At the same time, there is a decrease in the rate of photosynthesis and algae growth $[79,86,94,95]$.

Lighting above which growth slows down, according to Edwards et al. [15], does not differ among the taxonomic groups of marine phytoplankton and varies widely from 20 to $1000 \mu \mathrm{mol}$ photons $\mathrm{m}^{-2} \mathrm{~s}^{-1}$. Some species have low sensitivity to increased lighting and photoinhibition does not appear for a long time; others, on the contrary, have a very small range of optimal lighting. As a result, the total productivity of phytoplankton has a certain stabilization under variable lighting conditions. However, at the level of individual taxa, if the rate of photodamage exceeds the capabilities of protective mechanisms, a decrease in algal growth is observed. Different species show different resistance to photodamage. For example, in Phaeodactylum tricornutum, Chlorella vulgaris, and Tetradesmus obliquus (=Scenedesmus obliquus), saturation and subsequent photoinhibition were observed when exposed to light above 100 and $150 \mu \mathrm{mol}$ photons $\mathrm{m}^{-2} \mathrm{~s}^{-1}$, respectively [81,86], and no photoinhibition was observed in Microchloropsis salina (=Nannochloropsis salina), even at $850 \mu \mathrm{mol}$ photons $\mathrm{m}^{-2} \mathrm{~s}^{-1}$ [43]. In Chlorella sp. 800, a continuous increase in biomass productivity was noted without the manifestation of photoinhibition from $0.423 \mathrm{~g} \mathrm{~L}^{-1}$ day $^{-1}$ at $200 \mu \mathrm{mol}$ photons $\mathrm{m}^{-2} \mathrm{~s}^{-1}$, to $0.475 \mathrm{~g} \mathrm{~L}^{-1}$ day $^{-1}$ at $300 \mu \mathrm{mol}$ photons $\mathrm{m}^{-2} \mathrm{~s}^{-1}$, $0.62 \mathrm{~g} \mathrm{~L}^{-1}$ day $^{-1}$ at $400 \mu \mathrm{mol}$ photons $\mathrm{m}^{-2} \mathrm{~s}^{-1}$ and $0.707 \mathrm{~g} \mathrm{~L}^{-1}$ day $^{-1}$ at $500 \mu \mathrm{mol}$ photons $\mathrm{m}^{-2} \mathrm{~s}^{-1}$ [96]. Photoinhibition was not observed under lighting of $1800 \mu \mathrm{mol}$ photons $\mathrm{m}^{-2} \mathrm{~s}^{-1}$ in alpine snow alga Chlamydomonas nivalis [30].

Recent studies have shown that the strains Chlamydomonas reinhardtii cc124 and Chlorella ohadii, which are able to grow under very strong lighting - 3000 and $3500 \mu \mathrm{mol}$ photons $\mathrm{m}^{-2} \mathrm{~s}^{-1}$, respectively, exhibit high resistance to photoinhibition $[31,80]$. The strain Chlorella ohadii was isolated from a biological sand crust from the Sinai Desert in the northwestern Negev, Israel [31], and Chlamydomonas reinhardtii cc124 is a laboratory strain widely used as a wild type. It should be noted that this strain carries the agg1 mutation, which causes cells to float away from the light source (negative phototaxis), in contrast to cells of other wild type strains that float towards the light source (positive phototaxis) [97], requiring further study from the standpoint of high resistance to photoinhibition. 


\subsection{Effect of Light Intensity on Lipid Accumulation and Productivity}

An increase in light intensity leads to a shift in metabolic processes in algal cells. A number of studies have demonstrated that intense light leads to increased lipid synthesis and lipid excess accumulation. For example, in Tetradesmus obliquus, under lighting of $10 \mu \mathrm{mol}$ photons $\mathrm{m}^{-2} \mathrm{~s}^{-1}$, lipid synthesis does not occur at all, and with increasing lighting, they begin to be produced, and at $200 \mu \mathrm{mol}$ photons $\mathrm{m}^{-2} \mathrm{~s}^{-1}$, their number reaches maximum values - $45.31 \%$ of dry biomass [53]. However, a further increase in the light intensity (up to $1000 \mu \mathrm{mol}$ photons $\mathrm{m}^{-2} \mathrm{~s}^{-1}$ ) led to a decrease in the lipid content to $38.2 \%$ of dry biomass.

The light intensity that stimulates lipid synthesis in different types of microalgae is different (Table 3). The results obtained in the study of various Chlorella species and strains are quite indicative in this regard $[18,44,96,98]$.

Under conditions of increased lighting, in the composition of total lipids in many microalgae species, an increase in the content of neutral lipids (NLs) - triacylglyceride (TAG), is observed $[44,88]$. High light conditions caused the formation of NLs in Scenedesmus sp., Nannochloropsis sp., Botryococcus braunii, Isochrysis galbana, Phaeodactylum tricornutum $[47,99,100]$. Chlorella sp. at $400 \mu \mathrm{mol}$ photon $\mathrm{m}^{-2} \mathrm{~s}^{-1}$ had NLs 3 times higher than under lighting of $40 \mu \mathrm{mol}$ photon $\mathrm{m}^{-2} \mathrm{~s}^{-1}$, and the change in the number of membrane lipids had the opposite tendency [44]. However, this is not a common regularity. For example, Rhodomonas sp. with an increase in illumination from 150 to $600 \mu \mathrm{mol}$ photon $\mathrm{m}^{-2} \mathrm{~s}^{-1}$ increases the total fatty acid (TFA) content in membrane structures [84]. Nogueira et al. [99], having studied the effect of light intensity of 50,300, and $600 \mu \mathrm{mol}$ photons $\mathrm{m}^{-2} \mathrm{~s}^{-1}$ on the TAG content in Phaeodactylum tricornutum, recorded their maximum content under lighting of $600 \mu \mathrm{mol}$ photons $\mathrm{m}^{-2} \mathrm{~s}^{-1}$. When illuminated with $50 \mu \mathrm{mol}$ photons $\mathrm{m}^{-2} \mathrm{~s}^{-1}$, the TAG content reduced almost by half. Completely different results were obtained for Phaeodactylum tricornutum by Remmers et al. [81] when studying the effect of light intensity in the range 60-750 $\mu \mathrm{mol}$ photons $\mathrm{m}^{-2} \mathrm{~s}^{-1}$. The optimal lighting for TAG production was $60 \mu \mathrm{mol}$ photons $\mathrm{m}^{-2} \mathrm{~s}^{-1}$.

In general, as various studies show, the optimal light intensity for the highest lipid content and productivity is not the same for different taxa of microalgae. The composition of lipids itself is not the same within both large taxonomic groups and at the level of strains of the same species [12]. This issue has to be taken into account in further studies on the impact of lighting conditions on the content and production of lipids by microalgae. It should also be mentioned that stress in different taxonomic groups of microalgae can cause a shift in metabolic processes not only in terms of the accumulation of lipids but also in terms of other spare compounds, for example, starch [41].

\subsection{Changes in the Amount and Composition of Fatty Acids in Response to the Action of Light with Different Intensities}

Fatty acids in microalgae cells are in a free state or are part of neutral and polar lipids and fulfill both structural and functional roles [12]. Polar lipids (phospholipids, glycolipids, and betaine lipids) and associated fatty acids are structural components of cell membranes and play an important role in the organization of the light-harvesting complex of microalgae [101]. The fatty acid composition of lipids exhibits taxonomic specificity and also depends on environmental conditions [12]. Changes in light intensity are accompanied by restructuring of the fatty acid composition in microalgae [102]. Previous studies have shown that fatty acids can affect the properties of photosynthetically active membranes, and thereby participate in the biochemical adaptation of microalgae to changes in lighting conditions (for more details, see Wacker et al. [101]. Saturated (SFA) and unsaturated (UFA) fatty acids are believed to have different effects on photosystem II recovery after exposure to high intensity light, with PUFAs being reported to be easy targets for ROS [103]. It is also known that PUFAs are involved in the regulation of membrane fluidity, and a decrease in their number increases membrane rigidity [94]. The effect of light stress on 
fatty acid composition in comparison with normal growth conditions for some microalgae is summarized in Table 4.

An increase in the light intensity up to $500 \mu \mathrm{mol}$ photons $\mathrm{m}^{-2} \mathrm{~s}^{-1}$ during the cultivation of Chlorella sp. 800 resulted in a $26 \%$ increase in fatty acid production compared to cultivation at $200 \mu \mathrm{mol}$ photons $\mathrm{m}^{-2} \mathrm{~s}^{-1}$ [96]. A similar result of an increase in the content of TFAs and, in addition, arachidonic acid (ARA) were previously observed in Lobosphaera incisa (=Parietochloris incisa) under lighting of $400 \mu \mathrm{mol}$ photons $\mathrm{m}^{-2} \mathrm{~s}^{-1}$ [88]. According to the researchers, this is due to the large increase in biomass under such lighting. A high content of directly ARA in Lobosphaera incisa cultures was achieved with the simultaneous use of nitrogen starvation and exposure to light of $2000 \mu \mathrm{mol}$ photons $\mathrm{m}^{-2} \mathrm{~s}^{-1}$ [77].

Table 3. Influence of different light intensity on the content and productivity of lipids in microalgae.

\begin{tabular}{|c|c|c|c|c|c|c|}
\hline 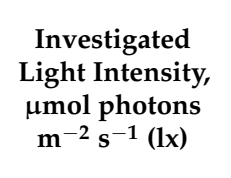 & $\begin{array}{l}\text { Optimal Light } \\
\text { Intensity for } \\
\text { Lipid Synthesis, } \\
\mu \mathrm{mol} \text { photons } \\
\mathrm{m}^{-2} \mathrm{~s}^{-1}\end{array}$ & Species and Strain & Class & $\begin{array}{c}\text { Lipid Content, } \\
\%\end{array}$ & $\begin{array}{c}\text { Lipid } \\
\text { Productivity, } \\
\text { mg L }^{-1} \text { day }^{-1}\end{array}$ & References \\
\hline $130,260,390,520$ & \multirow[t]{5}{*}{520} & Chlorella vulgaris & Trebouxiophyceae & \multirow[t]{5}{*}{22.24} & 19 & [18] \\
\hline 600 & & Chlorella vulgaris NIES-2170 & Trebouxiophyceae & & 290 & [98] \\
\hline 600 & & $\begin{array}{l}\text { Chloroidium viscosum SAG } \\
2338 \text { (=Chlorella viscosa) }\end{array}$ & Trebouxiophyceae & & 81 & [98] \\
\hline 600 & & $\begin{array}{l}\text { Chlorella sorokiniana } \\
\text { NIES-2169 }\end{array}$ & Trebouxiophyceae & & 39 & [98] \\
\hline 600 & & $\begin{array}{l}\text { Graesiella emersonii } \\
\text { NIES-2151 (=Chlorella } \\
\text { emersonii) }\end{array}$ & Trebouxiophyceae & & 230 & [98] \\
\hline $40,200,400$ & \multirow[t]{8}{*}{400} & Chlorella sp. & Trebouxiophyceae & $71.66(\mathrm{NL})$ & $51.36(\mathrm{NL})$ & [44] \\
\hline 200 & & Chlorella sp. 589 & Trebouxiophyceae & 30.2 & 102 & [96] \\
\hline 200 & & $\begin{array}{l}\text { Chloroidium saccharophilum } \\
477 \text { (=Chlorella saccharophila) }\end{array}$ & Trebouxiophyceae & 27.6 & 72,5 & [96] \\
\hline 200 & & Chlorella sp. 800 & Trebouxiophyceae & \multirow[t]{5}{*}{24.4} & 121 & [96] \\
\hline 600 & & $\begin{array}{c}\text { Parachlorella beijerinckii SAG } \\
2046\end{array}$ & Trebouxiophyceae & & 190 & [98] \\
\hline 600 & & $\begin{array}{c}\text { Parachlorella kessleri } \\
\text { NIES-2152 }\end{array}$ & Trebouxiophyceae & & 330 & [98] \\
\hline 600 & & $\begin{array}{c}\text { Parachlorella kessleri } \\
\text { NIES-2159 }\end{array}$ & Trebouxiophyceae & & 210 & [98] \\
\hline 600 & & $\begin{array}{c}\text { Parachlorella kessleri CCALA } \\
25\end{array}$ & Trebouxiophyceae & & 200 & {$[98]$} \\
\hline $50,250,400$ & 400 & Scenedesmus sp. 11-1 & Trebouxiophyceae & 41.1 & \multirow{4}{*}{46.13} & [104] \\
\hline $10-1000$ & \multirow[t]{3}{*}{200} & Tetradesmus obliquus & Trebouxiophyceae & 45.31 & & [53] \\
\hline 405 & & Choricystis sp. LBB13-AL045 & Trebouxiophyceae & & & [105] \\
\hline 200 & & $\begin{array}{l}\text { Botryococcus braunii KMITL } \\
2\end{array}$ & Trebouxiophyceae & 54.69 & & [106] \\
\hline $84,133,182$ & \multirow[t]{2}{*}{182} & Tetraselmis sp. $\mathrm{V}_{2}$ & Chlorodendrophyceae & 49.0 & & [89] \\
\hline 120 & & Tetraselmis suecica & Chlorophyceae & 26.1 & 47.3 & [107] \\
\hline $100-500$ & 300 & Chlamydomonas sp. JSC4 & Chlorophyceae & 43.1 & 312 & [108] \\
\hline $200-800$ & 500 & Ettlia sp. YC001 & Chlorophyceae & & 420 & [49] \\
\hline 100,200 & 200 & Dunaliella salina Y6 & Chlorophyceae & 14.5 & & [79] \\
\hline 90-300 & 300 & $\begin{array}{l}\text { Haematococcus lacustris } \\
\text { (=Haematococcus pluvialis) }\end{array}$ & Chlorophyceae & 32.99 & & [109] \\
\hline $40,200,400$ & 400 & Monoraphidium dybowskii Y2 & Chlorophyceae & $60.65(\mathrm{NL})$ & $49.71(\mathrm{NL})$ & [44] \\
\hline $50,300,600$ & 600 & Isochrysis galbana & Coccolithophyceae & 31.71 & 21.67 & [99] \\
\hline $50,300,600$ & 600 & Phaeodactylum tricornutum & Bacillariophyceae & 39.53 (TAG) & 31.39 (TAG) & [99] \\
\hline $60-750$ & 60 & Phaeodactylum tricornutum & Bacillariophyceae & & 112 (TAG) & [81] \\
\hline 170,700 & 700 & Nannochloropsis sp. & Eustigmatophyceae & 47 (TAG) & 360 (TAG) & [47] \\
\hline $50,100,200$ & 100 & Nannochloropsis sp. & Eustigmatophyceae & 31.3 & & [75] \\
\hline$(3000,4000,5000)$ & 5000 & $\begin{array}{l}\text { Arthrospira platensis } \\
\text { (=Spirulina platensis) }\end{array}$ & Cyanophyceae & 35.8 & & [50] \\
\hline
\end{tabular}


Table 4. The effect of light stress on fatty acid composition of different microalgae.

\begin{tabular}{|c|c|c|c|c|c|c|c|c|}
\hline \multirow{2}{*}{$\begin{array}{l}\text { Investigated } \\
\text { Light Intensity, } \\
\text { Mmol photons } \\
\mathrm{m}^{-2} \mathrm{~s}^{-1}\end{array}$} & \multirow{2}{*}{$\begin{array}{c}\text { Effective Light } \\
\text { Intensity for Fatty } \\
\text { Acid Synthesis, } \\
\mu \text { mol photons } \mathrm{m}^{-2} \mathrm{~s}^{-1}\end{array}$} & \multirow[b]{2}{*}{ Species } & \multirow[b]{2}{*}{ TFA } & \multirow[b]{2}{*}{ SFA } & \multirow[b]{2}{*}{ MUFA } & \multicolumn{2}{|c|}{ PUFA } & \multirow[b]{2}{*}{ References } \\
\hline & & & & & & $\begin{array}{l}\text { Total } \\
\text { PUFA }\end{array}$ & $\begin{array}{l}\text { Individual } \\
\text { Fatty Acid }\end{array}$ & \\
\hline $20,100,340$ & 20 & $\begin{array}{c}\text { Diacronema lutheri (=Pavlova } \\
\text { lutheri) }\end{array}$ & & & & $\uparrow$ & $\uparrow E P A$ & [110] \\
\hline $37.5,62.5,100$ & 37.5 & Chlorella vulgaris & & & $\uparrow$ & $\uparrow$ & & [111] \\
\hline $37.5,62.5,100$ & 100 & Chlorella vulgaris & & $\uparrow$ & & & & [111] \\
\hline 150,750 & 150 & Phaeodactylum tricornutum & & & & $\uparrow$ & $\uparrow E P A$ & [102] \\
\hline $50,125,300$ & 300 & $\begin{array}{l}\text { Chlorella vulgaris, } \\
\text { Tetradesmus obliquus }\end{array}$ & & & $\uparrow 18: 1$ & & $\downarrow 18: 3$ & [86] \\
\hline $50,125,325$ & 325 & Isochrysis galbana & & $\uparrow 16: 0$ & $\uparrow 18: 0$ & $\downarrow$ & $\begin{array}{c}\downarrow \mathrm{LA}, \downarrow \mathrm{ALA}, \\
\downarrow \text { SDA }\end{array}$ & [85] \\
\hline $20,100,340$ & 340 & Diacronema lutheri & & $\uparrow$ & & $\uparrow$ & $\uparrow \mathrm{DHA}$ & [110] \\
\hline $35,200,400$ & 400 & $\begin{array}{l}\text { Lobosphaera incisa } \\
\text { Entomoneis paludosa, }\end{array}$ & $\uparrow$ & & & $\uparrow$ & $\uparrow \mathrm{ARA}$ & [88] \\
\hline $30,100,400$ & 400 & $\begin{array}{l}\text { Nitzschia alexandrina, } \\
\text { Staurosira sp. }\end{array}$ & & & & $\downarrow$ & $\downarrow \mathrm{ARA}, \downarrow \mathrm{EPA}$ & [95] \\
\hline 200,500 & 500 & $\begin{array}{c}\text { Chlorella sp. } \\
\text { Nostoc carneum }\end{array}$ & $\uparrow$ & & & & & [96] \\
\hline 80,500 & 500 & $\begin{array}{c}\text { (= Nostoc spongiaeforme), } \\
\text { Phormidium corium }\end{array}$ & $\downarrow$ & & & & & [112] \\
\hline $\begin{array}{c}60,195,330,465 \\
600\end{array}$ & 600 & Rhodomonas sp. & & & & $\uparrow$ & $\uparrow E P A, \uparrow D H A$ & [84] \\
\hline 150,750 & 750 & Phaeodactylum tricornutum & & $\uparrow$ & & $\downarrow$ & & [102] \\
\hline $\begin{array}{c}5,25,50,100,250 \\
850\end{array}$ & 850 & Microchloropsis salina & $\uparrow$ & $\uparrow$ & & & $\downarrow$ EPA & [43] \\
\hline 250, 2000 & 2000 & Lobosphaera incisa & & & & & $\uparrow A R A$ & [77] \\
\hline
\end{tabular}

Down arrow $\downarrow$ means decrease, up arrow $\uparrow$ means increase.

Many studies have shown that intense light promotes the accumulation of SFAs in cells and a decrease in UFAs and PUFAs as well. A decrease in the production of PUFAs, ARA, and eicosapentaenoic acid (EPA) in Entomoneis paludosa NCC18.2, Nitzschia alexandrina NCC33, and Staurosira sp. NCC182 with an increase in light intensity from 30 to $400 \mu \mathrm{mol}$ photons $\mathrm{m}^{-2} \mathrm{~s}^{-1}$ was recorded in studies by Cointet et al. [95]. They concluded that low light and no nitrogen restrictions resulted in better photosynthetic energy-saving potential of the three strains, and therefore a more profitable approach. In Phaeodactylum tricornutum, light of $150 \mu \mathrm{mol}$ photons $\mathrm{m}^{-2} \mathrm{~s}^{-1}$ led to an increase in the production of PUFAs (16.59\%), including EPA (5.72\%). In contrast, irradiation with $750 \mu \mathrm{mol}$ photons $\mathrm{m}^{-2} \mathrm{~s}^{-1}$ led to an increase in SFAs and a decrease in PUFA concentrations in the fatty acid distribution [102].

In the green microalgae Chlorella vulgaris, Tetradesmus obliquus, an increase in light intensity from 50 to $300 \mu \mathrm{mol}$ photons $\mathrm{m}^{-2} \mathrm{~s}^{-1}$ led to a decrease in the linolenic 18:3 acid content and an increase in the oleic 18:1 acid content, which is important for improving the quality of biodiesel in its production from microalgae [86]. Khoeyi et al. [111] previously reported that in Chlorella vulgaris, the maximum percentage of total SFAs (33.38\%) was recorded at $100 \mu \mathrm{mol}$ photons $\mathrm{m}^{-2} \mathrm{~s}^{-1}$ and a photoperiod 16:8 $\mathrm{h}$ (light:dark), while the maximum production of monounsaturated fatty acids (MUFAs) $15.93 \%$ and PUFAs $27.40 \%$ were recorded at $37.5 \mu \mathrm{mol}$ photons $\mathrm{m}^{-2} \mathrm{~s}^{-1}$ and photoperiod 8:16 $\mathrm{h}$ (light:dark).

Microchloropsis salina showed a sharp increase in TFAs containing increased amounts of palmitic 16:0 and palmitoleic 16:1 acids under bright light, indicating a possible accumulation of TAG due to photooxidative stress. Lower lighting results in an increase in the relative content of UFAs [43]. Mishra et al. [85] observed in Isochrysis galbana the replacement of the accumulation of one fatty acid group, including myristic 14:0, linoleic 18:2 (LA), $\alpha$-linolenic 18:3 (ALA), and stearidonic 18:4 (SDA) acids, with a second fatty acid group, including palmitic 16:0, and oleic 18:1 acids, under conditions of nitrogen limitation and high light intensity. In Diacronema lutheri (=Pavlova lutheri), PUFA content, especially EPA, were significantly higher in low light, and levels of SFAs and docosahexaenoic acid (DHA) were significantly higher in bright light [110]. 
Fatty acid desaturation is considered to be an important factor in increasing the resistance of Synechococcus sp. PCC 7942 to strong light, especially at low temperatures [113]. Bhandari and Sharma [112] observed a decrease in the content of phospholipids and glycolipids in the cyanobacteria Nostoc spongiiforme and Phormidium corium when exposed to strong light $500 \mu \mathrm{mol}$ photons $\mathrm{m}^{-2} \mathrm{~s}^{-1}$. At the same time, the level of UFAs in total lipids and glycolipids remained unchanged in both species, but the level of SFAs decreased. This slightly changed the ratio in favor of UFAs at high light. No effect on the number of double bonds in fatty acid molecules when the light intensity changes from 200 to 500 was noted for Chlorella sp. 800 [96].

Thus, the available data on changes in the content of SFA and UFA in response to changes in light intensity are contradictory. It has been suggested that at high light intensity, microalgal cells use excess energy to produce storage lipids, mainly SFA and MUFA, which are usually involved in the formation of thylakoid membranes, and at low light levels, the PUFA content increases, mainly SDA, EPA, and octadecapentaenoic 18:5 omega- 3 acids. The increase in the content of MUFAs (including oleic 18:1 acid) is associated with its central role in the PUFA synthesis system [85]. It is also shown that the active functioning of photosystem I, caused by a change in the light intensity, is accompanied by an increase in omega-3 desaturation of fatty acids. There is a correlation between the formation of omega3 fatty acids in monogalactosyldiacylglycerols and the formation of reaction centers of photosystems, as well as between the biosynthesis of omega- 6 fatty acids and the formation of light-harvesting complexes of photosystems. Omega-3 desaturation of fatty acids can be considered as one of the quick adaptive responses to changes in light intensity; it does not always lead to an increase in the total lipid unsaturation index and can be associated with the "transition states" of photosystems [114].

It is reported that the change in the composition of fatty acids in response to the action of intense illumination may be due to the specificity of the fatty acid composition of individual taxa of microalgae. It may also be related to differences in the strategy of light acclimatization of different species [101].

\subsection{Production of Carotenoids When Changing Light Intensity}

Carotenoids in cells are both bound and free. The pathways of biosynthesis and transformation of carotenoids in microalgal cells are being thoroughly studied and information about this is available in a number of works $[20,64,68]$. Carotenoids play an important role in the photosynthesis processes of microalgae, as additional pigments, as well as in the mechanisms of photoprotection when exposed to high intensity light. Photoprotective mechanisms involving carotenoids in algae are quite diverse and have been discussed in detail in a number of recent works $[67,70,115,116]$.

One of the main mechanisms of photoprotection is based on the ability of some xanthophylls to participate in reversible light-dependent reactions, in which the excess excitation energy of chlorophylls is dissipated in the form of heat. This mechanism is called non-photochemical quenching and is well documented $[15,63,117]$. In algae, the most common xanthophyll cycles are violaxanthin and diadinoxanthin. The violaxanthin cycle is based on the mutual transformation of xanthophylls of violaxanthin, antheraxanthin, and zeaxanthin. In bright light, violaxanthin is converted to zeaxanthin via the antheraxanthin intermediate, while in low light, zeaxanthin is converted back to violaxanthin. The diadinoxanthin cycle includes interconversions of acetylenic (having one triple bond) xanthophylls. With excessive light, diadinoxanthin is converted to diatoxanthin, and with low light, the opposite reaction is observed $[115,118,119]$.

In addition to non-photochemical quenching, carotenoids can be involved in the chemical or physical suppression of ${ }^{1} \mathrm{O}_{2}$, which is formed under conditions of high light intensity. It is believed that $\beta$-carotene quenches ${ }^{1} \mathrm{O}_{2}$ in the photosystem II reaction center, which is the main site of ${ }^{1} \mathrm{O}_{2}$ formation [15]. Carotenoids in cells can also act as filters that reduce the amount of light reaching the photosynthetic apparatus [67]. It is reported that 
some carotenoids can accumulate in microalgae cells only under long-term exposure to strong light [64].

The ability of microalgae to accumulate carotenoids in large quantities makes them valuable objects for biotechnological production. On the world market, there is an increase in interest in carotenoids from natural sources, including microalgae [11]. Microalgae such as Dunaliella salina, Haematococcus lacustris (=Haematococcus pluvialis), and some Chlorella are rich sources of carotenoids $[37,38,48,66]$. In microalgae capable of both autotrophic and heterotrophic growth (for example, Haematococcus lacustris and Chromochloris zofingiensis, formerly known as Chlorella zofingiensis), heterotrophic conditions can significantly increase the productivity of biomass, but they cannot provide large amounts of pigments, including commercially valuable ones [120]. Exposure to high-intensity lighting increases carotenoid production in Haematococcus lacustris [37,121], Dunaliella salina [48,79], Chromochloris zofingiensis [122], Tetradesmus obliquus [123], Nostoc calcicola [124], etc. (Table 5). The composition of carotenoids in different microalgae species is not the same $[21,68]$. These species-specific features are reflected in the composition of carotenoids that accumulate under the action of light stress.

Table 5. Carotenoid accumulation at different light intensities.

\begin{tabular}{|c|c|c|c|c|c|c|}
\hline $\begin{array}{l}\text { Investigated } \\
\text { Light Intensity, } \\
\mu \mathrm{mol} \text { photons } \\
\mathrm{m}^{-2} \mathrm{~s}^{-1}\end{array}$ & $\begin{array}{l}\text { Optimal Light } \\
\text { Intensity for } \\
\text { Carotenoid } \\
\text { Synthesis, } \mu \mathrm{mol} \\
\text { photons } \mathrm{m}^{-2} \mathrm{~s}^{-1}\end{array}$ & Species and Strain & Carotenoid & $\begin{array}{l}\text { Content in } \\
\text { Dry Weight, } \\
\mathrm{mg} \mathrm{g}^{-1}\end{array}$ & $\begin{array}{l}\text { Productivity, } \\
\mathrm{mg} \mathrm{L}^{-1} \\
\text { day }^{-1}\end{array}$ & References \\
\hline $36.7,69.5,102.3$ & 69.5 & Tetradesmus obliquus & all carotenoids & 374.30 & & [123] \\
\hline $21,42,63$ & 63 & Nostoc calcicola & all carotenoids & 6.88 & & [124] \\
\hline 40,160 & 40 & Phormidium sp. & all carotenoids & 4.62 & & [92] \\
\hline 1200 & & $\begin{array}{c}\text { Haematococcus lacustris } \\
\text { CCAP } 34 / 7\end{array}$ & Astaxanthin & 590.31 & & [121] \\
\hline 350 & & Haematococcus lacustris & Astaxanthin & 21.8 & & [125] \\
\hline $50,100,200,400$ & 400 & Chromochloris zofingiensis & Astaxanthin & 2.88 & 9.9 & [122] \\
\hline $90,460,920$ & 460,920 & Chromochloris zofingiensis & Astaxanthin & 1.5 & & [126] \\
\hline 350 & & $\begin{array}{l}\text { Chromochloris zofingiensis } \\
\text { Coelastrella oocystiformis }\end{array}$ & Astaxanthin & 6.3 & & [125] \\
\hline 350 & & $\begin{array}{l}\text { (=Scotiellopsis } \\
\text { oocystiformis })\end{array}$ & Astaxanthin & 6.4 & & [125] \\
\hline 350 & & Neochloris wimmeri & Astaxanthin & 19.3 & & [125] \\
\hline 350 & & Scenedesmus vacuolatus & Astaxanthin & 1.5 & & [125] \\
\hline 350 & & Protosiphon botryoides & Astaxanthin & 14.3 & & {$[125]$} \\
\hline 1200 & & $\begin{array}{c}\text { Haematococcus lacustris } \\
\text { CCAP } 34 / 7\end{array}$ & Zeaxanthin & 108.50 & & [121] \\
\hline $\begin{array}{c}200,500,1000 \\
1500\end{array}$ & 1500 & Dunaliella salina DF15 & $\begin{array}{c}\text { all-trans and 9-cis } \\
\beta \text {-carotene }\end{array}$ & & 3.5 and 2.3 & {$[48]$} \\
\hline $\begin{array}{c}200,500,1000 \\
1500\end{array}$ & 1500 & Dunaliella salina DF17 & $\begin{array}{l}\text { all-trans and 9-cis } \\
\beta \text {-carotene }\end{array}$ & & 1.3 and 0.2 & {$[48]$} \\
\hline $\begin{array}{c}200,500,1000 \\
1500\end{array}$ & 1500 & Dunaliella salina DF40 & $\begin{array}{l}\text { all-trans and 9-cis } \\
\beta \text {-carotene }\end{array}$ & & 2.6 and 2.0 & [48] \\
\hline $\begin{array}{c}200,500,1000 \\
1500\end{array}$ & 1500 & $\begin{array}{c}\text { Dunaliella salina CCAP } \\
19 / 30\end{array}$ & $\begin{array}{c}\text { all-trans and 9-cis } \\
\beta \text {-carotene }\end{array}$ & & 3.2 and 0.2 & [48] \\
\hline $\begin{array}{c}200,500,1000 \\
1500\end{array}$ & 1500 & $\begin{array}{c}\text { Dunaliella bardawil UTEX } \\
2538 \text { (=Dunaliella salina) }\end{array}$ & $\begin{array}{l}\text { all-trans } \\
\beta \text {-carotene }\end{array}$ & & 2.9 and 2.2 & [48] \\
\hline $\begin{array}{c}200,500,1000 \\
1500\end{array}$ & 1000 & $\begin{array}{l}\text { Dunaliella bardawil UTEX } \\
2538 \text { (=Dunaliella salina) }\end{array}$ & 9-cis $\beta$-carotene & & 2.9 and 2.2 & [48] \\
\hline 1200 & & $\begin{array}{c}\text { Haematococcus lacustris } \\
\text { CCAP } 34 / 7\end{array}$ & $\beta$-carotene & 59.99 & & [124] \\
\hline $33,170,280$ & $33\left(35^{\circ} \mathrm{C}\right)$ & Tetraselmis sp. CTP4 & $\beta$-carotene & 4.41 & & [127] \\
\hline $33,170,280$ & $170\left(35^{\circ} \mathrm{C}\right)$ & Tetraselmis sp. CTP4 & $\beta$-carotene & 3.21 & & [127] \\
\hline $33,170,280$ & $280\left(30^{\circ} \mathrm{C}\right)$ & Tetraselmis sp. CTP4 & Lutein & 2.24 & & [127] \\
\hline $33,170,280$ & $170\left(35^{\circ} \mathrm{C}\right)$ & Tetraselmis sp. CTP4 & Lutein & 3.17 & & [127] \\
\hline $90,460,920$ & 90 & Chromochloris zofingiensis & Lutein & 4.0 & & [126] \\
\hline $\begin{array}{c}92,230,368,460 \\
690,920,1495\end{array}$ & 690 & Chlorella sorokiniana * & Lutein & 3.1 & & {$[128]$} \\
\hline 300 & & Tetradesmus obliquus FSP-3 & Lutein & & 4.08 & [78] \\
\hline
\end{tabular}


Astaxanthin and $\beta$-carotene are most interesting among carotenoids in the world market, and the demand for lutein and zeaxanthin is also growing $[11,13]$. $\beta$-carotene is the most widespread carotenoid in microalgae. It is the primary carotenoid. It takes part in photosynthesis and photoprotection. $\beta$-carotene is a biosynthetic precursor of xanthophylls such as zeaxanthin, antheraxanthin, violaxanthin, and neoxanthin. Large amounts of $\beta$-carotene, as well as lutein and zeaxanthin, are produced in Dunaliella salina [48]. It is a known fact that the production of these carotenoids in Dunaliella salina increases with increasing light intensity. Thus, an increase in lighting from 100 to $200 \mu$ mol photons $\mathrm{m}^{-2} \mathrm{~s}^{-1}$ increased the accumulation of $\beta$-carotene in Dunaliella salina $\mathrm{Y} 6$ by $31.5 \%$ [79]. In other studies, Dunaliella strains (DF15, DF17, DF40, UTEX 253) demonstrated an increase in $\beta$-carotene productivity under lighting of more than $200 \mu \mathrm{mol}$ photons $\mathrm{m}^{-2} \mathrm{~s}^{-1}$ and maximum productivity values (up to $3.5 \mathrm{mg} \mathrm{L}^{-1}$ day $^{-1}$ ) were noted at $1500 \mu \mathrm{mol}$ photons $\mathrm{m}^{-2} \mathrm{~s}^{-1}[48]$.

Astaxanthin is a secondary carotenoid belonging to the xanthophyll group. Its precursor is $\beta$-carotene [129]. Astaxanthin has 13 conjugated double bonds arranged as alternating single-double bonds. This configuration confers astaxanthin strong antioxidant properties thereby scavenging ROS and neutralizing free radicals. It is reported that when exposed to stressful conditions, some microalgae synthesize and accumulate astaxanthin in significant quantities [68]. Known astaxanthin producers are Haematococcus lacustris [37,121,130,131], and Chromochloris zofingiensis [122,132,133]. Smaller amounts of astaxanthin were found in Neochloris wimmeri, Scenedesmus vacuolatus [125], and Chlamydomonas nivalis [134].

High light intensity is one of the most effective factors for stimulating astaxanthin synthesis in microalgae [37]. There are positive results of an increase in the productivity of astaxanthin when exposed to high intensity light (100 and $400 \mu \mathrm{mol}$ photons $\mathrm{m}^{-2} \mathrm{~s}^{-1}$ ) on heterotrophically grown cultures of Haematococcus lacustris NIES-14, which have previously undergone the acclimatization procedure with moderate light intensity $(25$ and $50 \mu \mathrm{mol}$ photons $\mathrm{m}^{-2} \mathrm{~s}^{-1}$ ) [22]. Using this strategy, the productivity of astaxanthin was obtained up to $10.5 \mathrm{mg} \mathrm{L}^{-1} \mathrm{day}^{-1}$, and the most efficient light was $100 \mu \mathrm{mol}$ photons $\mathrm{m}^{-2} \mathrm{~s}^{-1}$. In other studies, Haematococcus lacustris JNU35 achieved an astaxanthin productivity of $18.1 \mathrm{mg} \mathrm{L}^{-1}$ day $^{-1}$ using $150 \mu \mathrm{mol}$ photons $\mathrm{m}^{-2} \mathrm{~s}^{-1}$ and then $300 \mu \mathrm{mol}$ photons $\mathrm{m}^{-2} \mathrm{~s}^{-1}$ lighting [135]. A similar strategy of stepped light changing from $50 \mu \mathrm{mol}$ photons $\mathrm{m}^{-2} \mathrm{~s}^{-1}$ to $400 \mu \mathrm{mol}$ photons $\mathrm{m}^{-2} \mathrm{~s}^{-1}$ was applied to Chromochloris zofingiensis ATCC 30412 and also increased astaxanthin synthesis to $2.7 \mathrm{mg} \mathrm{g}^{-1}$ of dry biomass and $9.9 \mathrm{mg} \mathrm{L}^{-1}$ day $^{-1}$, respectively. The results obtained under autotrophic conditions were 4.0 and 2.5 times higher than those obtained under heterotrophic conditions [122].

Pigment $\alpha$-carotene is less common than $\beta$-carotene. It is known that in the pathways of carotenoid conversion in algal cells, $\alpha$-carotene is a precursor of lutein [64]. The content of lutein in cells is affected by high light intensity. It is believed to be involved in the quenching of excited forms of chlorophyll and prevent the formation of ROS [119]. In Tetraselmis sp. CTP4 $\beta$-carotene content was maximal at a light intensity of $33 \mu$ mol photons $\mathrm{m}^{-2} \mathrm{~s}^{-1}$, while the lutein content increased 1.5 times at higher light intensities-170 and $280 \mu \mathrm{mol}$ photons $\mathrm{m}^{-2} \mathrm{~s}^{-1}$ [127]. Light of $170 \mu \mathrm{mol}$ photons $\mathrm{m}^{-2} \mathrm{~s}^{-1}$ for 2 days contributed to the high content in Tetraselmis sp. CTP4 of both lutein and $\beta$-carotene: $3.17 \pm 0.18$ and $3.21 \pm 0.18 \mathrm{mg} \mathrm{g}^{-1}$ of dry biomass, respectively [127]. In Auxenochlorella protothecoides, the highest productivity of lutein in culture with a heterotrophic-photoautotrophic transition reached $12.36 \mathrm{mg} \mathrm{L}^{-1} \mathrm{day}^{-1}$ on the seventh day. The light intensity at the autotrophic stage of cultivation corresponded to $4000 \mathrm{~lx}$ [120].

Thus, an increase in light intensity, taking into account species-specific features, can be used to stimulate the synthesis of carotenoids in microalgae, including $\beta$-carotene, lutein and astaxanthin.

\section{Influence of Spectral Composition of Light}

Pigments included in the structure of photosynthetic complexes of microalgae absorb photons from different parts of the light spectrum. Different microalgae taxonomic groups 
have different compositions of photosynthetic pigments and, accordingly, differ in the spectrum breadth that can be used in photosynthesis. For the maximum speed of photosynthesis, the spectral composition of light should be optimal for the pigment composition of the photosynthetic complex of a particular type of microalgae [39].

The use of LEDs as a light source allows both monochromatic lighting of microalgae cultures and simultaneous lighting with a light flux of a certain spectral composition. It is reported that the use of this technology can improve the efficiency of photochemical reactions [73] and the profitability of production [71,76]. It is also extremely important that the light flux of a special spectral composition can change metabolic processes in microalgae cells, shifting them towards the predominant accumulation of proteins, carbohydrates, or lipids [39]. Jungandreas et al. [136] reported that the transition from red to blue light in Phaeodactylum tricornutum increases the lipid content, and the reverse transition from blue to red light promotes the synthesis of carbohydrates. Blue light increases carbohydrate content, and the addition of green light can increase protein content in Arthrospira platensis (=Spirulina platensis) [137].

Various studies have examined the effects of red, yellow, green, and blue light on microalgae compared to each other and white light. The effect of monochromatic and mixed lighting on the growth of microalgae, lipid accumulation, and the composition of fatty acids and carotenoids was also studied (Table 6).

Table 6. Effect of monochromatic LED illumination on microalgae.

\begin{tabular}{|c|c|c|c|c|c|c|c|c|}
\hline \multirow{3}{*}{ LED } & \multirow{3}{*}{$\begin{array}{c}\text { Light } \\
\text { Intensity, } \\
\mu \mathrm{mol} \\
\text { photons } \\
\mathrm{m}^{-2} \mathrm{~s}^{-1}\end{array}$} & \multirow{3}{*}{ Species } & \multicolumn{5}{|c|}{ Stimulating Effect in Decreasing Order } & \multirow{3}{*}{ References } \\
\hline & & & \multirow{2}{*}{ Biomass } & \multirow{2}{*}{ Lipid } & \multicolumn{2}{|c|}{ Fatty Acids } & \multirow[b]{2}{*}{ Carotenoid } & \\
\hline & & & & & $\begin{array}{l}\text { MUFA, } \\
\text { PUFA }\end{array}$ & $\begin{array}{l}\text { Individual } \\
\text { Fatty Acids }\end{array}$ & & \\
\hline $\begin{array}{l}\text { white, red, } \\
\text { blue, green }\end{array}$ & 60 & Botryococcus braunii & $\begin{array}{l}\text { red }>\text { white }> \\
\text { blue }>\text { green }\end{array}$ & $\begin{array}{l}\text { red }>\text { white }> \\
\text { blue }>\text { green }\end{array}$ & & & & [138] \\
\hline $\begin{array}{l}\text { white, red, } \\
\text { blue, green, } \\
\text { yellow }\end{array}$ & 100 & Chlorella vulgaris & $\begin{array}{l}\text { white }>\text { red }> \\
\text { blue }>\text { yellow } \\
\quad>\text { green }\end{array}$ & & & $\begin{array}{l}\uparrow \mathrm{EPA}, \uparrow \mathrm{DHA} \\
\text { green }>\text { yellow }\end{array}$ & & [139] \\
\hline $\begin{array}{l}\text { white, red, } \\
\text { blue, green, } \\
\text { yellow }\end{array}$ & & Chlorella vulgaris & $\begin{array}{l}\text { white }>\text { red }> \\
\text { blue }>\text { yellow } \\
>\text { green }\end{array}$ & $\begin{array}{c}\text { blue }>\text { red }> \\
\text { white }>\text { green } \\
>\text { yellow }\end{array}$ & & & $\begin{array}{l}\text { yellow }>\text { green } \\
>\text { white }>\text { red }> \\
\text { blue }\end{array}$ & [39] \\
\hline $\begin{array}{l}\text { white, red, } \\
\text { blue, green, } \\
\text { yellow }\end{array}$ & & Tetradesmus obliquus & $\begin{array}{c}\text { red }>\text { blue }> \\
\text { white }>\text { yellow } \\
>\text { green }\end{array}$ & $\begin{array}{c}\text { blue }>\text { red }> \\
\text { white }>\text { green } \\
>\text { yellow }\end{array}$ & & & $\begin{array}{l}\text { yellow }>\text { green } \\
>\text { white }>\text { red }> \\
\text { blue }\end{array}$ & [39] \\
\hline red & & $\begin{array}{l}\text { Tetraselmis suecica } \\
\text { Chlorella vulgaris, }\end{array}$ & & & & $\uparrow E P A$ & & [24] \\
\hline $\begin{array}{l}\text { white, red, } \\
\text { blue }\end{array}$ & & $\begin{array}{l}\text { Auxenochlorella pyrenoidosa } \\
\text { (=Chlorella pyrenoidosa), } \\
\text { Scenedesmus quadricaud, } \\
\text { Tetradesmus obliquus }\end{array}$ & $\begin{array}{l}\text { blue }>\text { red }> \\
\text { white }\end{array}$ & & $\begin{array}{l}\uparrow \text { PUFA } \\
\text { blue }\end{array}$ & $\uparrow A L A$ & & [140] \\
\hline $\begin{array}{l}\text { white, red, } \\
\text { blue, green, } \\
\text { yellow }\end{array}$ & 100 & Diacronema lutheri & $\begin{array}{l}\text { blue }>\text { red }> \\
\text { green }>\text { yellow }\end{array}$ & & & $\begin{array}{c}\uparrow E P A, \uparrow D H A \\
\text { yellow }>\text { green }\end{array}$ & & [139] \\
\hline $\begin{array}{l}\text { white, red, } \\
\text { blue, green, } \\
\text { yellow }\end{array}$ & 100 & $\begin{array}{l}\text { Porphyridium purpureum } \\
\text { (=Porphyridium cruentum) }\end{array}$ & $\begin{array}{l}\text { green }>\text { blue }> \\
\text { yellow }>\text { red }\end{array}$ & & & $\begin{array}{l}\uparrow E P A, \uparrow D H A \\
\text { red }>\text { blue }\end{array}$ & & [139] \\
\hline $\begin{array}{l}\text { white, red, } \\
\text { yellow }\end{array}$ & & Phaeodactylum tricornutum & $\begin{array}{l}\text { red }>\text { white }> \\
\text { yellow }\end{array}$ & red $>$ white & & $\begin{array}{l}\text { omega- } 3, \\
\text { omega- } 6 \text { white } \\
>\text { red }\end{array}$ & & [72] \\
\hline red & & Phaeodactylum tricornutum & & & $\begin{array}{l}\downarrow \text { MUFA } \\
\uparrow \text { PUFA }\end{array}$ & & & [72] \\
\hline $\begin{array}{l}\text { white, red, } \\
\text { blue }\end{array}$ & $52^{\mathrm{a}}$ & Isochrysis galbana & $\uparrow$ blue & $\uparrow$ blue & & $\uparrow$ DHA blue & & [141] \\
\hline $\begin{array}{l}\text { white, red, } \\
\text { blue, green, } \\
\text { yellow }\end{array}$ & & Arthospira platensis & $\begin{array}{l}\text { red }>\text { white }> \\
\text { blue }>\text { yellow } \\
\quad>\text { green }\end{array}$ & $\begin{array}{c}\text { blue }>\text { red }> \\
\text { white }>\text { green } \\
>\text { yellow }\end{array}$ & & & $\begin{array}{l}\text { green }>\text { yellow } \\
>\text { white }>\text { red }> \\
\text { blue }\end{array}$ & [39] \\
\hline
\end{tabular}

Down arrow $\downarrow$ means decrease, up arrow $\uparrow$ means increase. ${ }^{\text {a }}$ Intermittent light.

Red light stimulated biomass formation in Phaeodactylum tricornutum [72], red and blue light in Scenedesmus sp. [142], red and yellow in Nannochloropsis sp. [143]. Okumura et al. [76] found that monochromatic blue and mixed red-green-blue LEDs contributed to the formation of the highest biomass in Botryococcus braunii $\left(0.22\right.$ and $0.39 \mathrm{mg} \mathrm{mL}^{-1} \mathrm{~d}^{-1}$, respectively) and the highest relative growth rate $\left(9.20 \pm 2.16\right.$ and $9.47 \pm 2.67 \mu \mathrm{g} \mathrm{mL}^{-1} \mathrm{~d}^{-1}$, respectively). Good results in increasing biomass are achieved with the simultaneous 
use of blue and red LEDs in Chlamydomonas reinhardtii [144], Arthrospira platensis [137], Auxenochlorella pyrenoidosa,$=$ Chlorella pyrenoidosa [145]. In Arthrospira platensis, the highest biomass formation rates were observed under red lighting, and the lowest under blue lighting [91,146]. Somewhat different results were obtained by Prates et al. [147] in Spirulina sp. LEB 18. Blue, green, red, and white LEDs increased biomass productivity and maximum specific growth rate in Spirulina sp. LEB 18; the maximum values were achieved with red LEDs, and with green ones, the highest concentration of phycocyanin was noted [147].

In Parachlorella kessleri UTEX 398, red light stimulates cell formation, while blue light stimulates cell growth [148]. The authors believe this can be used in the Parachlorella kessleri production run by first applying red light to obtain the desired cell concentration and then switching to blue light to increase cell size.

An increase in biomass productivity and lipid production in Tetraselmis sp., Nannochloropsis sp., Chlorella vulgaris, Isochrysis galbana was achieved with the use of blue LEDs [71,75,141,149,150]. Red light stimulates lipid formation in Botryococcus braunii [138], Nannochloropsis sp. [143], red and blue-in Arthrospira platensis, Chlorella vulgaris, Tetradesmus obliquus, Diacronema lutheri $[39,139]$. In Rhodomonas sp., blue and red lighting decreases biomass production, while green lighting increases it [151]. This is explained by the more efficient use of light energy due to the increased absorption of green and blue light waves by phycoerythrin, chlorophyll, and carotenoids of Rhodomonas sp. Green light has a stimulating effect on lipid synthesis in Porphyridium purpureum,$=$ Porphyridium cruentum [139].

When Chlorella vulgaris was grown in blue light at three different light intensities $\left(100,200\right.$, and $300 \mu \mathrm{mol}$ photons $\left.\mathrm{m}^{-2} \mathrm{~s}^{-1}\right)$, the maximum lipid content $(23.5 \%)$ was obtained by lighting of $200 \mu \mathrm{mol}$ photons $\mathrm{m}^{-2} \mathrm{~s}^{-1}$ with blue light and photoperiod 12:12 $\mathrm{h}$ light:dark [75]. When using intermittent blue light with a cycle of $50 \mu \mathrm{s} / 50 \mu \mathrm{s}$ (light:dark), the lipid content in Isochrysis galbana reached $155 \mathrm{mg} \mathrm{L}^{-1}$, and with constant white light with a photon flux density of $104 \mu \mathrm{mol}$ photons $\mathrm{m}^{-2} \mathrm{~s}^{-1}$ with a cycle 12:12 h (light:dark) $98 \mathrm{mg} \mathrm{L}^{-1}$. Culturing under intermittent blue light also led to the highest accumulation of DHA in Isochrysis galbana [141].

Red light in Phaeodactylum tricornutum stimulated the formation of PUFAs, and the amount of MUFAs decreased [72]. The use of red LEDs led to an increase in the content of EPA in the biomass of Tetraselmis suecica [24], EPA and DHA in the biomass of Porphyridium purpureum, while in the biomass of Diacronema lutheri, Chlorella vulgaris, an increase in the content of EPA and DHA occurred during lighting with yellow and green LEDs [139]. Blue light in Chlorella vulgaris, Auxenochlorella pyrenoidosa, Scenedesmus quadricauda, Tetradesmus obliquus stimulated the formation of PUFAs and directly ALA [140].

A high content of carotenoids was obtained in the presence of green LED lighting in Arthrospira platensis and yellow LED lighting in Chlorella vulgaris and Tetradesmus obliquus. The highest content of carotenoids was in Arthrospira platensis $\left(6.1 \mathrm{mg} \mathrm{g}^{-1}\right)$. The second largest result was recorded, respectively, with yellow and green LED lighting [39].

The results obtained in various studies indicate that the use of red light, as well as blue, improves the biomass productivity of microalgae of various taxonomic groups. It is known that the absorption maxima of chlorophylls are in the red and blue regions of the light spectrum, which ensures the most intense photosynthesis when using red and blue rays. Carotenoids, as additional pigments, actively absorb the blue-violet part of the spectrum and transfer the absorbed energy to chlorophyll. The significance of blue rays during the growth of microalgae and their productivity is enhanced by carotenoids.

\section{Influence of Duration and Frequency of Lighting}

The growth and metabolism of photoautotrophic microalgae is greatly influenced by the duration and frequency of lighting [84]. When cultivating microalgae, both continuous lighting and alternation of light and dark cycles, as well as light flashes or pulsed lighting, are used [46]. It is assumed that the use of lighting systems with dark cycles can increase the productivity of microalgae by increasing the efficiency of light absorption and reduce energy consumption, which is important for increasing the profitability of biotechnological 
production of microalgae. In addition, it is reported that continuous lighting can initiate photoinhibition processes, while the use of dark periods, including short-term ones, can help restore damage to photosystems [54].

By changing the photoperiod duration and varying the light intensity, it is possible to change the biochemical composition of microalgae. For example, Nostoc calcicola at a light intensity of $21 \mu \mathrm{mol}$ photons $\mathrm{m}^{-2} \mathrm{~s}^{-1}$ and a photoperiod of 8:16 light:darkness accumulated proteins and phycobiliproteins, and at a light intensity of $63 \mu \mathrm{mol}$ photons $\mathrm{m}^{-2} \mathrm{~s}^{-1}$ and longer illumination (16:8 light:dark)—carbohydrates and carotenoids [124].

An increase of Rhodomonas sp. biomass yield by $22 \%$ was achieved at a cycle $16: 8 \mathrm{~h}$ (light:dark) and lighting of $600 \mu \mathrm{mol}$ photons $\mathrm{m}^{-2} \mathrm{~s}^{-1}$ compared to constant lighting of $150 \mu \mathrm{mol}$ photons $\mathrm{m}^{-2} \mathrm{~s}^{-1}$ [84]. Also, the realization of a cycle light:dark made it possible to increase the content of TFAs in the biomass of Rhodomonas sp. by $19 \%$ and EPA + DHA content by almost $14 \%$ compared to the same levels for constant lighting conditions. The studies have shown that the use of light and dark cycles allows choosing the most appropriate time for collecting biomass. Thus, the best time to obtain biomass of Rhodomonas sp. with maximum EPA + DHA is before the start of the light cycle, and if maximum TFA content is required, the best time is between 5-9 $\mathrm{h}$ after the start of lighting.

The duration of the light period affects not only the growth of microalgae, but also the lipid content. For example, growing Nannochloropsis sp. in three different cycles of the photoperiod (24:0 h, 18:6 h, and 12:12 h of light:dark) and different lighting intensities (50, 100, and $200 \mu \mathrm{mol}$ photons $\mathrm{m}^{-2} \mathrm{~s}^{-1}$ ) showed that a light intensity of $100 \mu \mathrm{mol}$ photons $\mathrm{m}^{-2} \mathrm{~s}^{-1}$ and a photoperiod 18:6 $\mathrm{h}$ (light:dark) was the most productive and produced a lipid content of 31.3\% [75]. Increased biomass production and lipid content in Nannochloropsis sp. was obtained using a flashing light with a 45:15 min (light:dark) cycle [54].

Manipulations with the photoperiod duration and the light intensity make it possible to alter the production of carotenoids by microalgae. For example, in Nostoc calcicola, an increase in the light intensity from 21 to $63 \mu \mathrm{mol}$ photons $\mathrm{m}^{-2} \mathrm{~s}^{-1}$ and the photoperiod duration from 8:16 to $16: 8 \mathrm{~h}$ (light:dark) led to an increase in the content of carotenoids [124]. High light intensity and prolonged photoperiods were favorable for increasing the concentration of astaxanthin in Haematococcus lacustris cultures [37].

Using light of different wavelengths and varying the photoperiod duration, changes in the production characteristics of microalgae are also achieved. For example, white light with a cycle $24: 0 \mathrm{~h}$ (light:dark) is better than blue and red light and a cycle 12:12 $\mathrm{h}$ (light:dark) for the growth of Haematococcus lacustris, as well as lipid and astaxanthin production [38].

Another strategy for altering microalgae growth and lipid production is the use of pulsed light. It has been demonstrated that even strong light (for example, 1000-1200 $\mu \mathrm{mol}$ photons $\mathrm{m}^{-2} \mathrm{~s}^{-1}$ ) exceeding the saturation point of photosynthesis can be used for the microalgae growth [45]. In experiments with pulsed light, cells not only were able to avoid photodamage, but also used the energy from the pulses with the same efficiency as with dim continuous light. Moreover, it was found that the intensity of light flashes is not very important for growth. The results of the growth of Microchloropsis salina under light flashes of 1200 and $350 \mu \mathrm{mol}$ photons $\mathrm{m}^{-2} \mathrm{~s}^{-1}$ were similar. The authors' observations confirmed the importance of such a parameter as the duration of a light pulse. The optimal duration of light pulses was found to be around $10 \mathrm{~ms}$. It is known that after photon absorption by the photosystem, 1-15 ms are needed to reboot the system before it is ready to receive the next photon. Under short illumination, even with strong light, most photons are used for photosynthesis and do not lead to the formation of ROS, which then causes photoinhibition [45]. Cultivation of Isochrysis galbana at a flux density of $52 \mu \mathrm{mol}$ photons $\mathrm{m}^{-2} \mathrm{~s}^{-1}$ using white, red and blue light at a frequency of $10,000 \mathrm{~Hz}$ in the form of cycles $50 \mu \mathrm{s} / 50 \mu \mathrm{s}$ (light:dark) allowed to find out that pulsed white light contributes to better growth than continuous white light, and lipid production was higher with intermittent blue light [141]. However, the use of pulsed light does not always lead to the stimulation of microalgae growth. It was noted that illumination conditions of 1200 photons $\mathrm{m}^{-2} \mathrm{~s}^{-1}$ at 
$10 \mathrm{~Hz}$ and 350 photons $\mathrm{m}^{-2} \mathrm{~s}^{-1}$ at $30 \mathrm{~Hz}$ lead to the greatest growth of Microchloropsis salina, and light 1200 photons $\mathrm{m}^{-2} \mathrm{~s}^{-1}$ at $1-5 \mathrm{~Hz}$ to growth inhibition [45].

\section{Simultaneous Use of Light and Other Stresses}

It is well documented that exposure of microalgae to more than one stress at the same time, for example, high light intensity and high salinity or high light intensity and lack of nitrogen, phosphorus, can contribute to a stronger effect on the productivity of algae and their ability to accumulate lipids, valuable carotenoids $[37,95,106]$.

The combination of mild salt stress $(50 \mathrm{mM} \mathrm{NaCl})$ and light exposure resulted in greater lipid production in Chlamydomonas reinhardtii CC124 compared to heterotrophic conditions. However, a high concentration of $\mathrm{NaCl}(200 \mathrm{mM})$ caused irreversible damage to Chlamydomonas reinhardtii CC124 cells [94]. An increased susceptibility to photoinhibition was also observed in Arthrospira platensis under simultaneous exposure to light and salt stress [152]. An increase in the light intensity from 100 to $200 \mu \mathrm{mol}$ photons $\mathrm{m}^{-2} \mathrm{~s}^{-1}$ was accompanied by an increase in the growth rate of Arthrospira platensis, while the addition of $\mathrm{NaCl}$ in the amount of 0.5 and $0.75 \mathrm{M}$ did not increase the growth rate with increasing lighting. This indicated a reduced ability of Arthrospira platensis to use light energy under conditions of increased $\mathrm{NaCl}$ concentration.

Bright light enhances salt stress-induced astaxanthin and lipid biosynthesis in the green alga Chromochloris zofingiensis [153]. The best condition for lipid and astaxanthin production in Haematococcus lacustris was high intensity light and nitrogen starvation [38]. Other studies found that phosphate starvation and light stress also increased astaxanthin productivity in Haematococcus lacustris. Limiting phosphates to $41 \mathrm{mg} \mathrm{L}^{-1}$ was most effective; $0.25 \times$ of the standard BBM scale and continuous light stress (5000 lx) [37].

Pelah et al. [69] believe that salt stress can replace light stress with respect to the induction of carotenoid production: Chromochloris zofingiensis cells grown in low light and subjected to salt stress and low nitrogen stress accumulated more secondary carotenoids than cells growing in high light and low nitrogen. At the same time, the best conditions for the accumulation of canthaxanthin in Chromochloris zofingiensis were salt stress and low lighting, and for the accumulation of astaxanthin, high lighting was required. Li et al. [132] suggested that stresses due to strong light and $\mathrm{NaCl}$ can stimulate the generation of various ROS, which, in turn, act on certain carotenogenic genes responsible for triggering enhanced carotenoid biosynthesis in Chromochloris zofingiensis.

Study of the combined effect of light (60-195-330-465-600 $\mu$ mol photons $\left.\mathrm{m}^{-2} \mathrm{~s}^{-1}\right)$ and temperature (15-20-25-30 ${ }^{\circ} \mathrm{C}$ ) on the production and biomass composition of Rhodomonas sp. showed that stable biomass production was observed under all conditions, with the exception of experiments carried out at $30{ }^{\circ} \mathrm{C}$, which led to cell death. The optimal temperature was $22-24{ }^{\circ} \mathrm{C}$ and light 110 to $220 \mu \mathrm{mol}$ photons $\mathrm{m}^{-2} \mathrm{~s}^{-1}$. The fatty acid profile was significantly influenced only by temperature, namely, higher EPA and DHA contents were found at lower temperatures $\left(15^{\circ} \mathrm{C}\right)$, and the maximum production rate of EPA + DHA was obtained at $20{ }^{\circ} \mathrm{C}$ and strong light conditions $(600 \mu \mathrm{mol}$ photons $\mathrm{m}^{-2} \mathrm{~s}^{-1}$ ) [84]. In Isochrysis galbana, the combined effect of temperature and light intensity increased the TAG content (from 18.59 to $31.71 \%$ ) and its accumulation productivity (from 11.76 to $21.67 \mathrm{mg} \mathrm{L}^{-1}$ day $^{-1}$ ) [99].

In general, the sensitivity of algae to lighting conditions changes with the adjustment of the temperature regime. Light limitation lowers the temperature optimum of the species by $\sim 5^{\circ} \mathrm{C}$. There is an indication that the light saturation point changes with temperature and decreases with decreasing temperature [154].

Thus, when assessing the impact of light on the growth of microalgae and their production characteristics, it is necessary to take into account the impact of other parameters: temperature, composition of the cultivation medium, $\mathrm{CO}_{2}$ concentration, etc. These issues are discussed in several research works $[47,51,69,85]$. However, the complexity and ambiguity of the observed dependencies do not allow us to single out general patterns which are applicable for various taxonomic algae groups and various combinations of parameters. 


\section{Conclusions}

Light is a prerequisite for the photoautotrophic growth of microalgae. Light intensity, spectral composition, duration, and frequency of lighting can act as an effective tool for regulating the growth of microalgae, changes in metabolism, and induction of compounds valuable from a biochemical point of view.

The optimal light intensity for the growth of microalgae usually lies in the following range: $26-400 \mu \mathrm{mol}$ photons $\mathrm{m}^{-2} \mathrm{~s}^{-1}$. Only a few species demonstrate extremely high adaptation to high levels of lighting (up to 3000-3500 $\mu \mathrm{mol}$ photons $\mathrm{m}^{-2} \mathrm{~s}^{-1}$ ) and, accordingly, highly effective photoprotection mechanisms.

An increase in light intensity leads to increasing the lipid synthesis. For maximum lipid productivity, various species and strains of microalgae need lighting of different intensities: from 60 to $700 \mu \mathrm{mol}$ photons $\mathrm{m}^{-2} \mathrm{~s}^{-1}$. Strong light facilitates the accumulation of lipid especially TAGs. Probably, this may be as a means to convert excess light to chemical energy to avoid photooxidative damage.

Exposure to high intensity light stimulates the formation of fatty acids and changes in their composition. The fatty acid composition, the ratio of the amount of SFAs and UFAs can affect the properties of membranes, the activity of photosystem I functioning and the processes of photosystem II recovery after exposure to high light intensity. Generally, there is an accumulation of SFAs, as well as MUFAs and a decrease in the number of PUFAs. However, some microalgae under intense lighting conditions can increase the production of ARA, EPA, and DHA.

High light intensity is one of the most effective factors in stimulating the synthesis of carotenoids, including $\beta$-carotene, lutein, and astaxanthin in microalgae.

The use of a light flux of a special spectral composition changes metabolic processes in microalgae cells, as well as the composition of compounds accumulated by cells. Red as well as blue LED lighting improves the biomass productivity of microalgae of various taxonomic groups.

Manipulations with the duration of the photoperiod make it possible to increase the microalgae productivity by increasing the efficiency of light absorption. A feature of using pulsed light is the ability to avoid photodamage of microalgae cells and create conditions for the most efficient absorption of light photons during a flash and restoration of photosystems in the period between flashes. This is because under pulsed light, even with strong light, the majority of photons are used for photosynthesis and do not lead to the formation of ROS, which then cause photoinhibition.

The optimal light conditions for photosynthesis, growth, accumulation of lipids, SFAs, MUFAs and PUFAs, carotenes differ both in different taxonomic groups and in different strains of the same species. Moreover, the available data are sometimes contradictory and ambiguous. Taking this into account, as well as the existing developments in this area, there are a number of new tasks for further research:

- unification of approaches to studying the effect of lighting on the growth and productivity of microalgae;

- $\quad$ finding out the optimal lighting conditions for the cultivation of biotechnologically valuable species and strains of microalgae;

- $\quad$ establishing relationships between changes in lighting conditions, including light intensity, spectral composition of light, duration of lighting, etc. and an increase in the synthesis of compounds valuable from a biochemical point of view by microalgae; - determination of the stimulatory effects of a combination of light stress with other types of stress on the growth and productivity of microalgae, taking into account the synthesis of valuable bioproducts (lipids, fatty acids, carotenoids).

In order to standardize the approaches to the study of the impact of light on the growth and productivity of microalgae, it is recommended not only to provide information on light parameters, cell density in cultures, volume of the medium used, its composition, and $\mathrm{CO}_{2}$ concentration in the experimental studies, but also to indicate the origin of strains. When using strains of natural origin, it is important to indicate the peculiarities of the lighting 
conditions of its habitat. They can be very different both for aquatic organisms and for terrestrial ones growing in open spaces, in caves, in deep soil layers, etc. In the future, this will simplify the analysis of the results obtained and the development of recommendations for biotechnological industries.

Author Contributions: Conceptualization, data curation, writing—original draft (lead), Y.M.; writing —original draft (equal), K.M.; finishing draft (equal), M.K.; investigation, designed the research (equal), S.M. All authors have read and agreed to the published version of the manuscript.

Funding: This publication is based on research carried out with financial support by the Russian Science Foundation (project number 20-74-10076) and by framework of the state assignment (theme 121041200194-7) for finishing the manuscript.

Institutional Review Board Statement: Not applicable.

Informed Consent Statement: Not applicable.

Data Availability Statement: Not applicable.

Conflicts of Interest: The authors declare that they have no conflict of interest.

\section{References}

1. Xiao, Y.; Guo, J.; Zhu, H.; Muhammad, A.; Deng, H.; Hu, Z.; Wu, Q. Inhibition of glucose assimilation in Auxenochlorella protothecoides by light. Biotechnol. Biofuels 2020, 13, 146. [CrossRef]

2. Park, J.E.; Zhang, S.; Han, T.H.; Hwang, S.J. The contribution ratio of autotrophic and heterotrophic metabolism during a mixotrophic culture of Chlorella sorokiniana. Int. J. Environ. Res. Public Health 2021, 18, 1353. [CrossRef]

3. Maltsev, Y.I.; Konovalenko, T.V.; Barantsova, I.A.; Maltseva, I.A.; Maltseva, K.I. Prospects of using algae in biofuel production. Regul. Mech. Biosyst. 2017, 8, 455-460. [CrossRef]

4. Barkia, I.; Saari, N.; Manning, S.R. Microalgae for high-value products towards human health and nutrition. Mar. Drugs 2019, 17, 304. [CrossRef] [PubMed]

5. Maltsev, Y.I.; Maltseva, I.A.; Kulikovskiy, M.S.; Maltseva, S.Y.; Sidorov, R.A. Analysis of a new strain of Pseudomuriella engadinensis (Sphaeropleales, Chlorophyta) for possible use in biotechnology. Russ. J. Plant Physiol. 2019, 66, 609-616. [CrossRef]

6. Levasseur, W.; Perré, P.; Pozzobon, V. A review of high value-added molecules production by microalgae in light of the classification. Biotechnol. Adv. 2020, 41, 107545. [CrossRef]

7. Maltsev, Y.; Gusev, E.; Maltseva, I.; Kulikovskiy, M.; Namsaraev, Z.; Petrushkina, M.; Filimonova, A.; Sorokin, B.; Golubeva, A.; Butaeva, G.; et al. Description of a new species of soil algae, Parietochloris grandis sp. nov., and study of its fatty acid profiles under different culturing conditions. Algal Res. 2018, 33, 358-368. [CrossRef]

8. Maltsev, Y.; Maltseva, I.; Maltseva, S.; Kociolek, J.P.; Kulikovskiy, M. A new species of freshwater algae Nephrochlamys yushanlensis sp. nov. (Selenastraceae, Sphaeropleales) and its lipid accumulation during nitrogen and phosphorus starvation. J. Phycol. 2021, 57, 606-618. [CrossRef]

9. Maltsev, Y.; Krivova, Z.; Maltseva, S.; Maltseva, K.; Gorshkova, E.; Kulikovskiy, M. Lipid accumulation by Coelastrella multistriata (Scenedesmaceae, Sphaeropleales) during nitrogen and phosphorus starvation. Sci. Rep. 2021, 11, 19818. [CrossRef]

10. Sathasivam, R.; Radhakrishnan, R.; Hashem, A.; Abd_Allah, E.F. Microalgae metabolites: A rich source for food and medicine. Saudi J. Biol. Sci. 2019, 26, 709-722. [CrossRef] [PubMed]

11. Silva, S.C.; Ferreira, I.C.F.R.; Dias, M.M.; Barreiro, F.M. Microalgae-derived pigments: A 10-year bibliometric review and industry and market trend analysis. Molecules 2020, 25, 3406. [CrossRef] [PubMed]

12. Maltsev, Y.; Maltseva, K. Fatty acids of microalgae: Diversity and applications. Rev. Environ. Sci. Biotechnol. 2021, 20, 515-547. [CrossRef]

13. Wan, X.; Zhou, X.R.; Moncalian, G.; Su, L.; Chen, W.C.; Zhu, H.Z.; Chen, D.; Gong, Y.M.; Huang, F.H.; Deng, Q.C. Reprogramming microorganisms for the biosynthesis of astaxanthin via metabolic engineering. Prog. Lipid Res. 2021, 81, 101083. [CrossRef]

14. Vecchi, V.; Barera, S.; Bassi, R.; Dall'osto, L. Potential and challenges of improving photosynthesis in algae. Plants 2020, 9, 67. [CrossRef]

15. Erickson, E.; Wakao, S.; Niyogi, K.K. Light stress and photoprotection in Chlamydomonas reinhardtii. Plant J. 2015, 82, 449-465. [CrossRef] [PubMed]

16. Cornejo-Corona, I.; Thapa, H.R.; Browne, D.R.; Devarenne, T.P.; Lozoya-Gloria, E. Stress responses of the oil-producing green microalga Botryococcus braunii Race B. PeerJ 2016, 4, e2748. [CrossRef] [PubMed]

17. Swaminathan, D.; Sirisha, K.; Suganya, B.; Sivasubramanian, V.; Vishal, B.S.; Anand, C.B.; Meyyappan, N. Studies on the effect of pulsed magnetic field on the productivity of algae grown in dye industry effluent. J. Appl. Biotechnol. Bioeng. 2017, 3, 409-413. [CrossRef]

18. Metsoviti, M.N.; Papapolymerou, G.; Karapanagiotidis, I.T.; Katsoulas, N. Effect of light intensity and quality on growth rate and composition of Chlorella vulgaris. Plants 2020, 9, 31. [CrossRef] 
19. Minhas, A.K.; Hodgson, P.; Barrow, C.J.; Adholeya, A. A review on the assessment of stress conditions for simultaneous production of microalgal lipids and carotenoids. Front. Microbiol. 2016, 7, 546. [CrossRef] [PubMed]

20. Novoveská, L.; Ross, M.E.; Stanley, M.S.; Pradelles, R.; Wasiolek, V.; Sassi, J.F. Microalgal carotenoids: A review of production, current markets, regulations, and future direction. Mar. Drugs 2019, 17, 640. [CrossRef]

21. Shi, T.Q.; Wang, L.R.; Zhang, Z.X.; Sun, X.M.; Huang, H. Stresses as first-line tools for enhancing lipid and carotenoid production in microalgae. Front. Bioeng. Biotechnol. 2020, 8, 610. [CrossRef] [PubMed]

22. Zhang, Z.; Wang, B.; Hu, Q.; Sommerfeld, M.; Li, Y.; Han, D. A new paradigm for producing astaxanthin from the unicellular green alga Haematococcus pluvialis. Biotechnol. Bioeng. 2016, 113, 2088-2099. [CrossRef] [PubMed]

23. Erst, A.A.; Gorbunov, A.B.; Erst, A.S. Effect of concentration, method of auxin application and cultivation conditions on in vitro rooting of bog blueberry (Vaccinium uliginosum L.). J. Berry Res. 2018, 8, 41-53. [CrossRef]

24. Abiusi, F.; Wijffels, R.H.; Janssen, M. Doubling of microalgae productivity by oxygen balanced mixotrophy. ACS Sustain. Chem. Eng. 2020, 8, 6065-6074. [CrossRef]

25. Maltseva, I.A.; Maltsev, Y.I.; Solonenko, A.N. Soil algae of the oak groves of the steppe zone of Ukraine. Int. J. Algae 2017, 19, 215-226. [CrossRef]

26. Maltsev, Y.; Maltseva, I. The influence of forest-forming tree species on diversity and spatial distribution of algae in forest litter. Folia Oecologica 2018, 45, 72-81. [CrossRef]

27. Mayer, D.; Dubinsky, Z.; Iluz, D. Light as a limiting factor for epilithic algae in the supralittoral zone of littoral caves. Front. Mar. Sci. 2016, 3, 18. [CrossRef]

28. Kulikovskiy, M.; Kapustin, D.; Glushchenko, A.; Sidelev, S.; Maltsev, Y.; Gusev, E.; Kezlya, E.; Shkurina, N.; Kuznetsova, I.; Kociolek, P. Morphological and molecular investigation of Gomphonema longissimum and related taxa from Malili lakes (Indonesia) with comments on diatom evolution in ancient lakes. Eur. J. Phycol. 2019, 55, 147-161. [CrossRef]

29. Popović, S.; Krizmanić, J.; Vidaković, D.; Karadžić, V.; Milovanović, Ž.; Pećić, M.; Subakov Simić, G. Biofilms in caves: Easy method for the assessment of dominant phototrophic groups/taxa in situ. Environ. Monit. Assess. 2020, 192, 720. [CrossRef] [PubMed]

30. Remias, D.; Lütz-Meindl, U.; Lütz, C. Photosynthesis, pigments and ultrastructure of the alpine snow alga Chlamydomonas nivalis. Eur. J. Phycol. 2005, 40, 259-268. [CrossRef]

31. Treves, H.; Raanan, H.; Finkel, O.M.; Berkowicz, S.M.; Keren, N.; Shotland, Y.; Kaplan, A. A newly isolated Chlorella sp. from desert sand crusts exhibits a unique resistance to excess light intensity. FEMS Microbiol. Ecol. 2013, 86, 373-380. [CrossRef] [PubMed]

32. Davey, M.P.; Norman, L.; Sterk, P.; Huete-Ortega, M.; Bunbury, F.; Loh, B.K.W.; Stockton, S.; Peck, L.S.; Convey, P.; Newsham, K.K.; et al. Snow algae communities in Antarctica: Metabolic and taxonomic composition. N. Phytol. 2019, 222, 1242-1255. [CrossRef] [PubMed]

33. Mendez, M.O.; Maier, R.M. Phytostabilization of mine tailings in arid and semiarid environments-An emerging remediation technology. Environ. Health Perspect. 2008, 116, 278-283. [CrossRef]

34. Orlekowsky, T.; Venter, A.; Van Wyk, F.; Levanets, A. Cyanobacteria and algae of gold mine tailings in the Northwest Province of South Africa. Nov. Hedwig. 2013, 97, 281-294. [CrossRef]

35. Solonenko, A.M.; Arabadzhy-Tipenko, L.I.; Kunakh, O.M.; Kovalenko, D.V. The role of ecological groups in the formation of cyanobacterial communities in the ecosystems of the North Azov region (Ukraine). Biosyst. Divers. 2020, 28, 216-223. [CrossRef]

36. Maltseva, I.A.; Maltsev, Y.I. Diversity of cyanobacteria and algae in dependence to forest-forming tree species and properties rocks of dump. Int. J. Environ. Sci. Technol. 2021, 18, 545-560. [CrossRef]

37. Liyanaarachchi, V.C.; Nishshanka, G.K.S.H.; Premaratne, R.G.M.M.; Ariyadasa, T.U.; Nimarshana, P.H.V.; Malik, A. Astaxanthin accumulation in the green microalga Haematococcus pluvialis: Effect of initial phosphate concentration and stepwise/continuous light stress. Biotechnol. Rep. 2020, 28, e0053. [CrossRef]

38. Wong, Y.K.; Ho, Y.H.; Lai, Y.T.; Tsang, P.M.; Chow, K.P.; Yau, Y.H.; Choi, M.C.; Ho, R.S.C. Effects of light intensity, illumination cycles on microalgae Haematococcus pluvialis for production of astaxanthin. J. Mar. Biol. Aquacult. 2016, 2, 1-6. [CrossRef]

39. Raqiba, H.; Sibi, G. Light emitting diode (LED) illumination for enhanced growth and cellular composition in three microalgae. Adv. Microb. Res. 2019, 3, 007. [CrossRef]

40. Airs, R.L.; Temperton, B.; Sambles, C.; Farnham, G.; Skill, S.C.; Llewellyn, C.A. Chlorophyll $f$ and chlorophyll $d$ are produced in the cyanobacterium Chlorogloeopsis fritschii when cultured under natural light and near-infrared radiation. FEBS Lett. 2014, 588, 3770-3777. [CrossRef]

41. Le, B.; Williams, P.J.; Laurens, L.M.L. Microalgae as biodiesel \& biomass feedstocks: Review \& analysis of the biochemistry, energetics \& economics. Energy Environ. Sci. 2010, 3, 554-590. [CrossRef]

42. Scandalios, J.G. Oxidative stress: Molecular perception and transduction of signals triggering antioxidant gene defenses. Braz. J. Med. Biol. Res. 2005, 38, 995-1014. [CrossRef]

43. Wagenen, J.V.; Miller, T.W.; Hobbs, S.; Hook, P.; Crowe, B.; Huesemann, M. Effects of light and temperature on fatty acid production in Nannochloropsis salina. Energies 2012, 5, 731-740. [CrossRef]

44. He, Q.; Yang, H.; Wu, L.; Hu, C. Effect of light intensity on physiological changes, carbon allocation and neutral lipid accumulation in oleaginous microalgae. Bioresour. Technol. 2015, 191, 219-228. [CrossRef] 
45. Sforza, E.; Simionato, D.; Giacometti, G.M.; Bertucco, A.; Morosinotto, T. Adjusted light and dark cycles can optimize photosynthetic efficiency in algae growing in photobioreactors. PLoS ONE 2012, 7, e38975. [CrossRef] [PubMed]

46. Zarmi, Y.; Gordon, J.M.; Mahulkar, A.; Khopkar, A.R.; Patil, S.D.; Banerjee, A.; Reddy, B.G.; Griffin, T.P.; Sapre, A. Enhanced algal photosynthetic photon efficiency by pulsed light. iScience 2020, 23, 101115. [CrossRef] [PubMed]

47. Pal, D.; Khozin-Goldberg, I.; Cohen, Z.; Boussiba, S. The effect of light, salinity, and nitrogen availability on lipid production by Nannochloropsis sp. Appl. Microbiol. Biotechnol. 2011, 90, 1429-1441. [CrossRef]

48. Xu, Y.; Ibrahim, I.M.; Wosu, C.I.; Ben-Amotz, A.; Harvey, P.J. Potential of new isolates of Dunaliella salina for natural $\beta$-carotene production. Biology 2018, 7, 14. [CrossRef]

49. Kim, S.; Moon, M.; Kwak, M.; Lee, B.; Chang, Y.K. Statistical optimization of light intensity and $\mathrm{CO}_{2}$ concentration for lipid production derived from attached cultivation of green microalga Ettlia sp. Sci. Rep. 2018, 8, 15390. [CrossRef] [PubMed]

50. Palanisamy, K.M.; Paramasivam, P.; Jayakumar, S.; Maniam, G.P.; Rahim, M.H.A.; Govindan, N. Economical cultivation system of microalgae Spirulina platensis for lipid production. In Proceedings of the IOP Conference Series: Earth and Environmental Science, Pekan, Malaysia, 19 June 2020; Volume 641. [CrossRef]

51. Hu, X.; Zhou, J.; Liu, B. Effect of algal species and light intensity on the performance of an air-lift-type microbial carbon capture cell with an algae-assisted cathode. RSC Adv. 2016, 6, 25094-25100. [CrossRef]

52. Environmental Growth Chambers. Available online: http://www.egc.com/useful_info_lighting.php (accessed on 13 October 2021).

53. Sforza, E.; Gris, B.; De Farias Silva, C.E.; Morosinotto, T.; Bertucco, A. Effects of light on cultivation of Scenedesmus obliquus in batch and continuous flat plate photobioreactor. Chem. Eng. Trans. 2014, 38, 211-216. [CrossRef]

54. Yustinadiar, N.; Manurung, R.; Suantika, G. Enhanced biomass productivity of microalgae Nannochloropsis sp. in an airlift photobioreactor using low-frequency flashing light with blue LED. Bioresour. Bioprocess. 2020, 7, 43. [CrossRef]

55. Gim, G.H.; Ryu, J.; Kim, M.J.; Kim, P.I.; Kim, S.W. Effects of carbon source and light intensity on the growth and total lipid production of three microalgae under different culture conditions. J. Ind. Microbiol. Biotechnol. 2016, 43, 605-616. [CrossRef] [PubMed]

56. Straka, L.; Rittmann, B.E. Effect of culture density on biomass production and light utilization efficiency of Synechocystis sp. PCC 6803. Biotechnol. Bioeng. 2018, 115, 507-511. [CrossRef] [PubMed]

57. Senge, M.O.; Ryan, A.A.; Letchford, K.A.; MacGowan, S.A.; Mielke, T. Chlorophylls, symmetry, chirality, and photosynthesis. Symmetry 2014, 6, 781-843. [CrossRef]

58. Greenwold, M.J.; Cunningham, B.R.; Lachenmyer, E.M.; Pullman, J.M.; Richardson, T.L.; Dudycha, J.L. Diversification of light capture ability was accompanied by the evolution of phycobiliproteins in cryptophyte algae. Proc. R. Soc. B 2019, 286, 20190655. [CrossRef]

59. Da Silva, J.C.; Lombardi, A.T. Pigments from Microalgae Handbook. Chlorophylls in Microalgae: Occurrence, Distribution, and Biosynthesis; Springer: Cham, Switzerland, 2020; pp. 1-18. [CrossRef]

60. Koh, H.G.; Kang, N.K.; Jeon, S.; Shin, S.E.; Jeong, B.R.; Chang, Y.K. Heterologous synthesis of chlorophyll b in Nannochloropsis salina enhances growth and lipid production by increasing photosynthetic efficiency. Biotechnol. Biofuels 2019, 12, 122. [CrossRef]

61. Bachvaroff, T.R.; Sanchez Puerta, M.V.; Delwiche, C.F. Chlorophyll c-containing plastid relationships based on analyses of a multigene data set with all four chromalveolate lineages. Mol. Biol. Evol. 2005, 22, 1772-1782. [CrossRef]

62. Chen, M.; Schliep, M.; Willows, R.D.; Cai, Z.L.; Neilan, B.A.; Scheer, H. A red-shifted chlorophyll. Science 2010, 329, 1318-1319. [CrossRef] [PubMed]

63. Takaichi, S.; Mochimaru, M.; Uchida, H.; Murakami, A.; Hirose, E.; Maoka, T.; Tsuchiya, T.; Mimuro, M. Opposite chilarity of $\alpha$-carotene in unusual cyanobacteria with unique chlorophylls, acaryochloris and prochlorococcus. Plant Cell Physiol. 2012, 53, 1881-1888. [CrossRef]

64. Kuczynska, P.; Jemiola-Rzeminska, M.; Strzalka, K. Photosynthetic pigments in diatoms. Mar. Drugs 2015, 13, 5847-5881. [CrossRef] [PubMed]

65. Stadnichuk, I.N.; Krasil'nikov, P.M.; Zlenko, D.V. Cyanobacterial phycobilisomes and phycobiliproteins. Microbiology 2015, 84, 101-111. [CrossRef]

66. Mulders, K.J.M.; Lamers, P.P.; Martens, D.E.; Wijffels, R.H. Phototrophic pigment production with microalgae: Biological constraints and opportunities. J. Phycol. 2014, 50, 229-242. [CrossRef] [PubMed]

67. Ladygin, V.G. Ways of biosynthesis, localization, metabolism and functions of carotenoids in chloroplasts of different types of algae. Issues Mod. Algol. 2014, 2. Available online: http:/ / www.algology.ru/52 (accessed on 13 October 2021).

68. Solovchenko, A.E. Recent breakthroughs in the biology of astaxanthin accumulation by microalgal cell. Photosynth. Res. 2015, 125, 437-449. [CrossRef] [PubMed]

69. Pelah, D.; Sintov, A.; Cohen, E. The effect of salt stress on the production of canthaxanthin and astaxanthin by Chlorella zofingiensis grown under limited light intensity. World J. Microbiol. Biotechnol. 2004, 20, 483-486. [CrossRef]

70. Fisher, N.L.; Campbell, D.A.; Hughes, D.J.; Kuzhiumparambil, U.; Halsey, K.H.; Ralph, P.J.; Suggett, D.J. Divergence of photosynthetic strategies amongst marine diatoms. PLoS ONE 2020, 15, e0244252. [CrossRef] [PubMed]

71. Teo, C.L.; Atta, M.; Bukhari, A.; Taisir, M.; Yusuf, A.M.; Idris, A. Enhancing growth and lipid production of marine microalgae for biodiesel production via the use of different LED wavelengths. Bioresour. Technol. 2014, 162, 38-44. [CrossRef] 
72. Sharma, N.; Fleurent, G.; Awwad, F.; Cheng, M.; Meddeb-Mouelhi, F.; Budge, S.M.; Germain, H.; Desgagné-Penix, I. Red light variation an effective alternative to regulate biomass and lipid profiles in Phaeodactylum tricornutum. Appl. Sci. 2020, $10,2531$. [CrossRef]

73. Schulze, P.S.C.; Barreira, L.A.; Pereira, H.G.C.; Perales, J.A.; Varela, J.C.S. Light emitting diodes (LEDs) applied to microalgal production. Trends Biotechnol. 2014, 32, 422-430. [CrossRef] [PubMed]

74. Morgunov, D.N.; Vasiliev, S.I. Investigation of the spectral characteristics of electrical light sources. Bull. Don Agrar. Sci. 2017, 2.

75. Atta, M.; Idris, A.; Bukhari, A.; Wahidin, S. Intensity of blue LED light: A potential stimulus for biomass and lipid content in fresh water microalgae Chlorella vulgaris. Bioresour. Technol. 2013, 148, 373-378. [CrossRef]

76. Okumura, C.; Saffreena, N.; Rahman, M.A.; Hasegawa, H.; Miki, O.; Takimoto, A. Economic efficiency of different light wavelengths and intensities using LEDs for the cultivation of green microalga Botryococcus braunii (NIES-836) for biofuel production. Environ. Prog. Sustain. Energy 2015, 34, 269-275. [CrossRef]

77. Cheng-Wu, Z.; Cohen, Z.; Khozin-Goldberg, I.; Richmond, A. Characterization of growth and arachidonic acid production of Parietochloris incisa comb. nov (Trebouxiophyceae, Chlorophyta). J. Appl. Phycol. 2002, 14, 453-460. [CrossRef]

78. Ho, S.H.; Chan, M.C.; Liu, C.C.; Chen, C.Y.; Lee, W.L.; Lee, D.J.; Chang, J.S. Enhancing lutein productivity of an indigenous microalga Scenedesmus obliquus FSP-3 using light-related strategies. Bioresour. Technol. 2014, 152, 275-282. [CrossRef]

79. Wu, M.; Zhu, R.; Lu, J.; Lei, A.; Zhu, H.; Hu, Z.; Wang, J. Effects of different abiotic stresses on carotenoid and fatty acid metabolism in the green microalga Dunaliella salina Y6. Ann. Microbiol. 2020, 70, 48. [CrossRef]

80. Virtanen, O.; Khorobrykh, S.; Tyystjärvi, E. Acclimation of Chlamydomonas reinhardtii to extremely strong light. Photosynth. Res. 2021, 147, 91-106. [CrossRef] [PubMed]

81. Remmers, I.M.; Martens, D.E.; Wijffels, R.H.; Lamers, P.P. Dynamics of triacylglycerol and EPA production in Phaeodactylum tricornutum under nitrogen starvation at different light intensities. PLoS ONE 2017, 12, e0175630. [CrossRef]

82. Gudvilovich, I.N.; Lelekov, A.S.; Maltsev, E.I.; Kulikovskii, M.S.; Borovkov, A.B. Growth of Porphyridium purpureum (Porphyridiales, Rhodophyta) and production of B-phycoerythrin under varying illumination. Russ. J. Plant Physiol. 2021, 68, 188-196. [CrossRef]

83. Vu, M.T.T.; Douëtte, C.; Rayner, T.A.; Thoisen, C.; Nielsen, S.L.; Hansen, B.W. Optimization of photosynthesis, growth, and biochemical composition of the microalga Rhodomonas salina-An established diet for live feed copepods in aquaculture. J. Appl. Phycol. 2016, 28, 1485-1500. [CrossRef]

84. Oostlander, P.C.; Van Houcke, J.; Wijffels, R.H.; Barbosa, M.J. Optimization of Rhodomonas sp. under continuous cultivation for industrial applications in aquaculture. Algal Res. 2020, 47, 101889. [CrossRef]

85. Mishra, N.; Prasad, S.M.; Mishra, N. Influence of high light intensity and nitrate deprivation on growth and biochemical composition of the marine microalgae Isochrysis galbana. Braz. Arch. Biol. Technol. 2019, 62, e19180398. [CrossRef]

86. Nzayisenga, J.C.; Farge, X.; Groll, S.L.; Sellstedt, A. Effects of light intensity on growth and lipid production in microalgae grown in wastewater. Biotechnol. Biofuels 2020, 13, 4. [CrossRef] [PubMed]

87. Rise, M.; Cohen, E.; Vishkautsan, M.; Cojocaru, M.; Gottlieb, H.E.; Arad, S.M. Accumulation of secondary carotenoids in Chlorella zofingiensis. J. Plant Physiol. 1994, 144, 287-292. [CrossRef]

88. Solovchenko, A.E.; Khozin-Goldberg, I.; Didi-Cohen, S.; Cohen, Z.; Merzlyak, M.N. Effects of light intensity and nitrogen starvation on growth, total fatty acids and arachidonic acid in the green microalga Parietochloris incisa. J. Appl. Phycol. 2008, 20, 245-251. [CrossRef]

89. Dammak, M.; Haase, S.M.; Miladi, R.; Ben Amor, F.; Barkallah, M.; Gosset, D.; Pichon, C.; Huchzermeyer, B.; Fendri, I.; Denis, M.; et al. Enhanced lipid and biomass production by a newly isolated and identified marine microalga. Lipids Health Dis. 2016, 15, 209. [CrossRef]

90. Kebede, E.; Ahlgren, G. Optimum growth conditions and light utilization efficiency of Spirulina platensis (= Arthrospira fusiformis) (Cyanophyta) from Lake Chitu, Ethiopia. Hydrobiologia 1996, 332, 99-109. [CrossRef]

91. Niangoran, U.; Tian, F.; Canale, L.; Haba, C.T.; Buso, D.; Zissis, G. Study of the LEDs spectrums influence on the Spirulina platensis growth in batch culture. In Proceedings of the 2018 IEEE International Conference on Environment and Electrical Engineering and 2018 IEEE Industrial and Commercial Power Systems Europe, Palermo, Italy, 12-15 June 2018; pp. 1-4. [CrossRef]

92. Hotos, G.N. Culture growth of the vyanobacterium Phormidium sp. in various valinity and light regimes and their influence on its phycocyanin and other pigments content. J. Mar. Sci. Eng. 2021, 9, 798. [CrossRef]

93. Włodarczyk, A.; Selão, T.T.; Norling, B.; Nixon, P.J. Newly discovered Synechococcus sp. PCC 11901 is a robust cyanobacterial strain for high biomass production. Commun. Biol. 2020, 3, 215. [CrossRef] [PubMed]

94. Fan, J.; Zheng, 1. Acclimation to $\mathrm{NaCl}$ and light stress of heterotrophic Chlamydomonas reinhardtii for lipid accumulation. J. Biosci. Bioeng. 2017, 124, 302-308. [CrossRef] [PubMed]

95. Cointet, E.; Wielgosz-Collin, G.; Bougaran, G.; Rabesaotra, V.; Gonçalves, O.; Méléder, V. Effects of light and nitrogen availability on photosynthetic efficiency and fatty acid content of three original benthic diatom strains. PLoS ONE 2019, 14, e0224701. [CrossRef] [PubMed]

96. Hempel, N.; Petrick, I.; Behrendt, F. Biomass productivity and productivity of fatty acids and amino acids of microalgae strains as key characteristics of suitability for biodiesel production. J. Appl. Phycol. 2012, 24, 1407-1418. [CrossRef] 
97. Ide, T.; Mochiji, S.; Ueki, N.; Yamaguchi, K.; Shigenobu, S.; Hirono, M.; Wakabayashi, K. Identification of the agg1 mutation responsible for negative phototaxis in a "wild-type" strain of Chlamydomonas reinhardtii. Biochem. Biophys. Rep. 2016, 7, $379-385$. [CrossRef] [PubMed]

98. Takeshita, T.; Ota, S.; Yamazaki, T.; Hirata, A.; Zachleder, V.; Kawano, S. Starch and lipid accumulation in eight strains of six Chlorella species under comparatively high light intensity and aeration culture conditions. Bioresour. Technol. 2014, 158, 127-134. [CrossRef] [PubMed]

99. Nogueira, K.D.P.; Silva, A.F.; Araújo, O.Q.F.; Chaloub, R.M. Impact of temperature and light intensity on triacylglycerol accumulation in marine microalgae. Biomass Bioenergy 2015, 72, 280-287. [CrossRef]

100. Shi, K.; Gao, Z.; Shi, T.Q.; Song, P.; Ren, L.J.; Huang, H.; Ji, X.J. Reactive oxygen species-mediated cellular stress response and lipid accumulation in oleaginous microorganisms: The state of the art and future perspectives. Front. Microbiol. 2017, 8, 793. [CrossRef]

101. Wacker, A.; Piepho, M.; Harwood, J.L.; Guschina, I.A.; Arts, M.T. Light-induced changes in fatty acid profiles of specific lipid classes in several freshwater phytoplankton species. Front. Plant Sci. 2016, 7, 264. [CrossRef] [PubMed]

102. Conceição, D.; Lopes, R.G.; Derner, R.B.; Cella, H.; Do Carmo, A.P.B.; Montes D'Oca, M.G.; Petersen, R.; Passos, M.F.; Vargas, J.V.C.; Galli-Terasawa, L.V.; et al. The effect of light intensity on the production and accumulation of pigments and fatty acids in Phaeodactylum tricornutum. J. Appl. Phycol. 2020, 32, 1017-1025. [CrossRef]

103. Jimbo, H.; Takagi, K.; Hirashima, T.; Nishiyama, Y.; Wada, H. Long-chain saturated fatty acids, palmitic and stearic acids, enhance the repair of photosystem II. Int. J. Mol. Sci. 2020, 21, 7509. [CrossRef]

104. Liu, J.; Yuan, C.; Hu, G.; Li, F. Effects of light intensity on the growth and lipid accumulation of microalga Scenedesmus sp. 11-1 under nitrogen limitation. Appl. Biochem. Biotechnol. 2012, 166, 2127-2137. [CrossRef]

105. Praharyawan, S.; Yunita Rahman, D.; Susilaningsih, D. Influence of light intensity on lipid productivity and fatty acids profile of Choricystis sp. LBB13-AL045 for biodiesel production. Res. J. Life Sci. 2018, 5, 128-139. [CrossRef]

106. Ruangsomboon, S. Effect of light, nutrient, cultivation time and salinity on lipid production of newly isolated strain of the green microalga, Botryococcus braunii KMITL 2. Bioresour. Technol. 2012, 109, 261-265. [CrossRef] [PubMed]

107. Xu, S.J.; Wu, K.C.; Chan, S.C.Y.; Yau, Y.H.; Chan, K.K.; Lee, F.W.F. Investigation of growth, lipid productivity, and fatty acid profiles in marine bloom-forming dinoflagellates as potential feedstock for biodiesel. J. Mar. Sci. Eng. 2020, 8, 381. [CrossRef]

108. Ho, S.H.; Nakanishi, A.; Ye, X.; Chang, J.S.; Chen, C.Y.; Hasunuma, T.; Kondo, A. Dynamic metabolic profiling of the marine microalga Chlamydomonas sp. JSC4 and enhancing its oil production by optimizing light intensity Luisa Gouveia. Biotechnol. Biofuels 2015, 8, 48. [CrossRef] [PubMed]

109. Damiani, M.C.; Popovich, C.A.; Constenla, D.; Leonardi, P.I. Lipid analysis in Haematococcus pluvialis to assess its potential use as a biodiesel feedstock. Bioresour. Technol. 2010, 101, 3801-3807. [CrossRef] [PubMed]

110. Guihéneuf, F.; Mimouni, V.; Ulmann, L.; Tremblin, G. Combined effects of irradiance level and carbon source on fatty acid and lipid class composition in the microalga Pavlova lutheri commonly used in mariculture. J. Exp. Mar. Biol. Ecol. 2009, 369, 136-143. [CrossRef]

111. Khoeyi, Z.A.; Seyfabadi, J.; Ramezanpour, Z. Effect of light intensity and photoperiod on biomass and fatty acid composition of the microalgae, Chlorella vulgaris. Aquac. Int. 2012, 20, 41-49. [CrossRef]

112. Bhandari, R.; Sharma, P.K. High-light-induced changes on photosynthesis, pigments, sugars, lipids and antioxidant enzymes in freshwater (Nostoc spongiaeforme) and marine (Phormidium corium) cyanobacteria. Photochem. Photobiol. 2006, 82, 702-710. [CrossRef] [PubMed]

113. Gombos, Z.; Kanervo, E.; Tsvetkova, N.; Sakamoto, T.; Aro, E.M.; Murata, N. Genetic enhancement of the ability to tolerate photoinhibition by introduction of unsaturated bonds into membrane glycerolipids. Plant Physiol. 1997, 115, 551-559. [CrossRef]

114. Klyachko-Gurvich, G.L.; Pronina, N.A.; Ladygin, V.G.; Tsoglin, L.N.; Semenenko, V.E. Uncoupled functioning of separate photosystems: 1. Characteristics of fatty acid desaturation and its role. Russ. J. Plant Physiol. 2000, 47, 603-612.

115. Giossi, C.; Cartaxana, P.; Cruz, S. Photoprotective role of neoxanthin in plants and algae. Molecules 2020, 25, 4617. [CrossRef] [PubMed]

116. Lacour, T.; Babin, M.; Lavaud, J. Diversity in xanthophyll cycle pigments content and related nonphotochemical quenching (NPQ) among microalgae: Implications for growth strategy and ecology. J. Phycol. 2020, 56, 245-263. [CrossRef] [PubMed]

117. Cui, Y.; Zhang, H.; Lin, S. Enhancement of non-photochemical quenching as an adaptive strategy under phosphorus deprivation in the dinoflagellate Karlodinium veneficum. Front. Microbiol. 2017, 8, 404. [CrossRef] [PubMed]

118. Lohr, M.; Wilhelm, C. Algae displaying the diadinoxanthin cycle also possess the violaxanthin cycle. Proc. Natl. Acad. Sci. USA 1999, 96, 8784-8789. [CrossRef]

119. Jahns, P.; Holzwarth, A.R. The role of the xanthophyll cycle and of lutein in photoprotection of photosystem II. Biochim. Biophys. Acta Bioenerg. 2012, 1817, 182-193. [CrossRef] [PubMed]

120. Xiao, Y.; He, X.; Ma, Q.; Lu, Y.; Bai, F.; Dai, J.; Wu, Q. Photosynthetic accumulation of lutein in Auxenochlorella protothecoides after heterotrophic growth. Mar. Drugs 2018, 16, 283. [CrossRef]

121. Galarza, J.I.; Arredondo Vega, B.O.; Villón, J.; Henríquez, V. Deesterification of astaxanthin and intermediate esters from Haematococcus pluvialis subjected to stress. Biotechnol. Rep. 2019, 23, e00351. [CrossRef] [PubMed]

122. Sun, Z.; Zhang, Y.; Sun, L.P.; Liu, J. Light elicits astaxanthin biosynthesis and accumulation in the fermented ultrahigh-density Chlorella zofinginesis. J. Agric. Food Chem. 2019, 67, 5579-5586. [CrossRef] 
123. Zapata, L.M.; Jiménez-Veuthey, M.; Zampedri, P.A.; Flores, A.B.; Zampedri, C.A.; Chabrillón, G. Effect of light stress and concentrations of nitrogen and carbon in the production of phytonutrients in the microalga Scenedesmus obliquus (Chlorophyceae, Chlorococcales). J. Algal Biomass Utln. 2020, 11, 9-22.

124. Khajepour, F.; Hosseini, S.A.; Ghorbani Nasrabadi, R.; Markou, G. Effect of light intensity and photoperiod on growth and biochemical composition of a local isolate of Nostoc calcicola. Appl. Biochem. Biotechnol. 2015, 176, 2279-2289. [CrossRef] [PubMed]

125. Orosa, M.; Valero, J.F.; Herrero, C.; Abalde, J. Comparison of the accumulation of astaxanthin in Haematococcus pluvialis and other green microalgae under N-starvation and high light conditions. Biotechnol. Lett. 2001, 23, 1079-1085. [CrossRef]

126. Del Campo, J.A.; Rodríguez, H.; Moreno, J.; Vargas, M.Á.; Rivas, J.; Guerrero, M.G. Accumulation of astaxanthin and lutein in Chlorella zofingiensis (Chlorophyta). Appl. Microbiol. Biotechnol. 2004, 64, 848-854. [CrossRef]

127. Schüler, L.M.; Santos, T.; Pereira, H.; Duarte, P.; Katkam, N.G.; Florindo, C.; Schulze, P.S.C.; Barreira, L.; Varela, J.C.S. Improved production of lutein and $\beta$-carotene by thermal and light intensity upshifts in the marine microalga Tetraselmis sp. CTP4. Algal Res. 2020, 45, 101732. [CrossRef]

128. Cordero, B.F.; Obraztsova, I.; Couso, I.; Leon, R.; Vargas, M.A.; Rodriguez, H. Enhancement of lutein production in Chlorella sorokiniana (chorophyta) by improvement of culture conditions and random mutagenesis. Mar. Drugs 2011, 9, 1607-1624. [CrossRef] [PubMed]

129. Lemoine, Y.; Schoefs, B. Secondary ketocarotenoid astaxanthin biosynthesis in algae: A multifunctional response to stress. Photosynth. Res. 2010, 106, 155-177. [CrossRef] [PubMed]

130. Wang, B.; Zarka, A.; Trebst, A.; Boussiba, S. Astaxanthin accumulation in Haematococcus pluvialis (Chlorophyceae) as an active photoprotective process under high irradiance. J. Phycol. 2003, 39, 1116-1124. [CrossRef]

131. Butler, T.O.; Mcdougall, G.J.; Campbell, R.; Stanley, M.S.; Day, J.G. Media screening for obtaining Haematococcus pluvialis red motile macrozooids rich in astaxanthin and fatty acids. Biology 2017, 7, 2. [CrossRef]

132. Li, Y.; Huang, J.; Sandmann, G.; Chen, F. High-light and sodium chloride stress differentially regulate the biosynthesis of astaxanthin in Chlorella zofingiensis (chlorophyceae). J. Phycol. 2009, 45, 635-641. [CrossRef] [PubMed]

133. Liu, J.; Sun, Z.; Gerken, H.; Liu, Z.; Jiang, Y.; Chen, F. Chlorella zofingiensis as an alternative microalgal producer of astaxanthin: Biology and industrial potential. Mar. Drugs 2014, 12, 3487-3515. [CrossRef]

134. Ǩezanka, T.; Nedbalová, L.; Sigler, K.; Cepák, V. Identification of astaxanthin diglucoside diesters from snow alga Chlamydomonas nivalis by liquid chromatography-atmospheric pressure chemical ionization mass spectrometry. Phytochemistry 2008, 69, 479-490. [CrossRef] [PubMed]

135. Wang, F.; Gao, B.; Wu, M.; Huang, L.; Zhang, C. A novel strategy for the hyper-production of astaxanthin from the newly isolated microalga Haematococcus pluvialis JNU35. Algal Res. 2019, 39, 101466. [CrossRef]

136. Jungandreas, A.; Costa, B.S.; Jakob, T.; Von Bergen, M.; Baumann, S.; Wilhelm, C. The acclimation of Phaeodactylum tricornutum to blue and red light does not influence the photosynthetic light reaction but strongly disturbs the carbon allocation pattern. PLoS ONE 2014, 9, e99727. [CrossRef]

137. Mao, R.; Guo, S. Performance of the mixed LED light quality on the growth and energy efficiency of Arthrospira platensis. Appl. Microbiol. Biotechnol. 2018, 102, 5245-5254. [CrossRef] [PubMed]

138. Acuapan-Hernandez, J.; Cañizares-Villanueva, R.O.; Cristiani-Urbina, E. Red light and nitrogen depletion stimulate the synthesis of lipids and n-alkadienes susceptible to be used as biofuels in Botryococcus braunii UTEX 2441 (Race A). Biotechnol. Indian J. 2017, $13,155$.

139. Kim, S.H.; Sunwoo, I.Y.; Hong, H.J.; Awah, C.C.; Jeong, G.T.; Kim, S.K. Lipid and unsaturated fatty acid productions from three microalgae using nitrate and light-emitting diodes with complementary LED wavelength in a two-phase culture system. Bioprocess Biosyst. Eng. 2019, 42, 1517-1526. [CrossRef] [PubMed]

140. Zhong, Y.; Jin, P.; Cheng, J.J. A comprehensive comparable study of the physiological properties of four microalgal species under different light wavelength conditions. Planta 2018, 248, 489-498. [CrossRef]

141. Yoshioka, M.; Yago, T.; Yoshie-Stark, Y.; Arakawa, H.; Morinaga, T. Effect of high frequency of intermittent light on the growth and fatty acid profile of Isochrysis galbana. Aquaculture 2012, 338-341, 111-117. [CrossRef]

142. Kim, T.H.; Lee, Y.; Han, S.H.; Hwang, S.J. The effects of wavelength and wavelength mixing ratios on microalgae growth and nitrogen, phosphorus removal using Scenedesmus sp. for wastewater treatment. Bioresour. Technol. 2013, 130, 75-80. [CrossRef]

143. Shin, W.S.; Jung, S.M.; Cho, C.H.; Woo, D.W.; Kim, W.; Kwon, J.H. Use of tar color additives as a light filter to enhance growth and lipid production by the microalga Nannochloropsis gaditana. Environ. Eng. Res. 2018, 23, 205-209. [CrossRef]

144. Wagner, I.; Steinweg, C.; Posten, C. Mono- and dichromatic LED illumination leads to enhanced growth and energy conversion for high-efficiency cultivation of microalgae for application in space. Biotechnol. J. 2016, 11, 1060-1071. [CrossRef] [PubMed]

145. Guo, H.; Fang, Z. Effect of light quality on the cultivation of Chlorella pyrenoidosa. In Proceedings of the 2nd International Symposium on Architecture Research Frontiers and Ecological Environment (ARFEE 2019), Guilin, China, 20-22 December 2019; Volume 143, p. 02033. [CrossRef]

146. Wang, C.Y.; Fu, C.C.; Liu, Y.C. Effects of using light-emitting diodes on the cultivation of Spirulina platensis. Biochem. Eng. J. 2007, 37, 21-25. [CrossRef]

147. Da Fontoura Prates, D.; Radmann, E.M.; Duarte, J.H.; De Morais, M.G.; Costa, J.A.V. Spirulina cultivated under different light emitting diodes: Enhanced cell growth and phycocyanin production. Bioresour. Technol. 2018, 256, 38-43. [CrossRef] 
148. Koc, C.; Anderson, G.A.; Kommareddy, A. Use of red and blue light-emitting diodes (LED) and fluorescent lamps to grow microalgae in a photobioreactor. Isr. J. Aquac. Bamidgeh 2013, 65. [CrossRef]

149. Das, P.; Lei, W.; Aziz, S.S.; Obbard, J.P. Enhanced algae growth in both phototrophic and mixotrophic culture under blue light. Bioresour. Technol. 2011, 102, 3883-3887. [CrossRef] [PubMed]

150. Zhang, Y.; Dong, F.; Jin, P. Effects of light-emitting diodes (LEDs) on the accumulation of lipid content in microalgae. In Proceedings of the 2nd International Conference on Sustainable Energy and Environment Protection (ICSEEP 2017), Changsha, Chine, 23-25 June 2017; pp. 184-189. [CrossRef]

151. Latsos, C.; Van Houcke, J.; Blommaert, L.; Verbeeke, G.P.; Kromkamp, J.; Timmermans, K.R. Effect of light quality and quantity on productivity and phycoerythrin concentration in the cryptophyte Rhodomonas sp. J. Appl. Phycol. 2021, 33, 729-741. [CrossRef]

152. Vonshak, A.; Kancharaksa, N.; Bunnag, B.; Tanticharoen, M. Role of light and photosynthesis on the acclimation process of the cyanobacterium Spirulina platensis to salinity stress. J. Appl. Phycol. 1996, 8, 119-124. [CrossRef]

153. Kou, Y.; Liu, M.; Sun, P.; Dong, Z.; Liu, J. High light boosts salinity stress-induced biosynthesis of astaxanthin and lipids in the green alga Chromochloris zofingiensis. Algal. Res. 2020, 50, 101976. [CrossRef]

154. Edwards, K.F.; Thomas, M.K.; Klausmeier, C.A.; Litchman, E. Phytoplankton growth and the interaction of light and temperature: A synthesis at the species and community level. Limnol. Oceanogr. 2016, 61, 1232-1244. [CrossRef] 